\title{
The Agro-Industrial Sugarcane System in Mexico: Current Status, Challenges and Opportunities
}

\author{
Héctor Emmanuel Sentíes-Herrera ${ }^{1}$, Fernando Carlos Gómez-Merino ${ }^{2}$, Apolonio Valdez-Balero ${ }^{3}$, \\ Hilda Victoria Silva-Rojas ${ }^{1} \&$ Libia Iris Trejo-Téllez ${ }^{1}$ \\ ${ }^{1}$ Colegio de Postgraduados, Campus Montecillo, Carretera México-Texcoco km 36.5, Montecillo, Estado de \\ México, Mexico \\ ${ }^{2}$ Colegio de Postgraduados, Campus Córdoba, Carretera Córdoba-Veracruz km 348, Congregación Manuel León, \\ Amatlán de los Reyes, Veracruz, Mexico \\ ${ }^{3}$ Colegio de Postgraduados, Campus Tabasco, Periférico Carlos A. Molina S/N, Carretera Cárdenas-Huimanguillo \\ km 3, H. Cárdenas, Tabasco, Mexico \\ Correspondence: Fernando Carlos Gómez-Merino, Colegio de Postgraduados, Campus Córdoba, Carretera \\ Córdoba-Veracruz km 348, Congregación Manuel León, Amatlán de los Reyes, Veracruz, Mexico. Tel: \\ 52-595-951-0198. E-mail: fernandg@colpos.mx
}

Received: December 16, 2013 Accepted: January 28, 2014 Online Published: March 15, 2014

doi:10.5539/jas.v6n4p26

URL: http://dx.doi.org/10.5539/jas.v6n4p26

\begin{abstract}
Sugarcane cultivation in Mexico occurs under a wide range of socioeconomic, environmental and agricultural conditions, with the last three harvests $(2010 / 2011,2011 / 2012$ and 2012/2013) providing yields ranging from

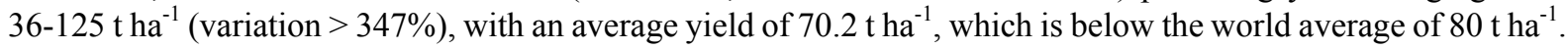
The total area allocated to sugarcane production in Mexico is close to 800 thousand hectares, and could rise to nearly 5 million hectares given adequate conditions for its cultivation. This activity generates approximately 1 million direct jobs, 2.2 million indirect jobs, and more than 2.5 billion dollars $(0.4 \%$ of GDP) per year. Climate change and the rapid market penetration of high fructose corn syrup are among the greatest threats to this agribusiness, including severe disintegration of production processes in the field, industry, commerce, and consumption of cane sugar. Technology lags, low investment, high processing costs and shortcomings in production sales are issues the industry must address by leveraging their resources and coordinating processing links to be more efficient and competitive. Political influence has imposed a suboptimal policy framework to achieve the projected potential. To overcome current lags in the field and refineries within the country, significant innovations across the value-chain are underway, including a robust breeding program, digitalization of sugarcane fields and novel investments in research and development. The sugarcane value-chain has great potential for Mexico, and exploiting this potential is possible if technological, organizational and commercial management innovations currently in progress in fields and factories are applied.
\end{abstract}

Keywords: Saccharum, mexican agro-industry, sugar yield, innovation

\section{Introduction}

Sugarcane (Saccharum spp.) is the most productive crop in the world due to its higher efficiency in photosynthetic capacity, and its ability to store sucrose in its stem. Sugarcane contributes $75 \%$ of the total sugar produced in the world with the remaining $25 \%$ produced from sugar-beets (Beta vulgaris L.). Its high biomass production and ease of growth make sugarcane one of the most interesting agricultural commodities globally, useful not only in food and feed, but also in the generation of inputs for bioenergy and chemical industries. Its cultivation covers an area over 25.4 million hectares in more than 130 countries and territories, with production of more than 1800 million tons, thus establishing sugarcane as the crop having the most acreage in the world (FAOSTAT, 2013). Average global production is approximately $80 \mathrm{tha}^{-1}$ (Waclawovsky, Sato, Lembke, Moore, \& Souza, 2010), although theoretical yields are estimated near $470 \mathrm{tha}^{-1}$ dry matter or $805 \mathrm{tha}^{-1}$ of fresh cane per year (Yadav, Jain, \& Rai, 2010; Dal-Bianco et al., 2012), which supports the hypothesis that increased future yields are possible. Diversification of products (transition from simple sugarcane mills to sugarcane biorefineries) utilizing the entire crop for a variety of environmentally friendly outcomes apart from sucrose, is the key factor in today's highly integrated sugar milling operations, generating a wide range of other products such as energy, human food, animal 
feed, manures, biofuels, ethyl alcohol and its derivatives. In fact, it is possible to derive more than 10000 new products from sucrose (Aguilar-Rivera, Rodríguez-Lagunes, \& Castillo-Morán, 2010). For small peasant farms, a profitable alternative is natural brown sugar, for which production in Mexico fluctuates between 100000 and 500 000 t year $^{-1}$ (Méndez, Elorza, Maruri, Elorza, \& Martínez, 2013). This enormous performance capability for a sugarcane multipurpose culture is highly important for its continued use, including its bio-factory potential for the synthesis of high-value sugars, biopolymers and pharmacological proteins (Gómez-Merino, Trejo-Téllez, \& Sentíes-Herrera, 2014).

In Mexico, sugarcane agribusiness generates more than 930000 direct jobs and 2.2 million indirect jobs, in 15 states and 227 municipalities (9.2\% of all municipalities in Mexico) (Secretaría de Economía, 2012) that are grouped into six production areas (Northwest, Pacific, Center, Northeast, Gulf and South) (Aguilar-Rivera, Rodríguez, Enríquez, Castillo, \& Herrera, 2012). In this value-chain, enormous strengths are related to soil quality and suitable climate where it is grown, and where the primary producer organizations and industry are well-structured, although complex. However, there are major challenges that need to be addressed to ensure a successful future for this value-chain. Recently, Aguilar-Rivera, Espinosa-López, Herrera, Castillo, and Lagunes (2013) performed an analysis of competitiveness of the Mexican sugarcane industry, taking into account Porter's diamond model (Porter, 2008). Within this analysis, actor conditions; demand conditions; firm strategy, structure and rivalry; related and supporting industries; as well as role of the government and changes in the Mexican sugarcane value-chain are depicted. Herein, we further analyze more in-depth the state of the art for the sugarcane production system in Mexico, and describe its strengths and current and future challenges to ensure its consolidation through innovative strategies that may increase productivity and profitability.

\section{History and Current Economic Importance of Sugarcane in Mexico}

Since its introduction in Mexico nearly 500 years ago, sugarcane has become an integral part of the national economy. Although its development has gone through serious critical stages since its inception, it is now established as one of the most traditional agribusiness activities of significance in the country's economic development (Aguilar-Rivera, 2013), which now faces significant consolidation challenges to remain as an innovative and globally competitive value-chain.

The Mexican sugar industry has a historical-structural model depicting the operation of a traditional and rooted socioeconomic system after the triumph of the Mexican Revolution. This model is characterized by a supply of goods with low added value and low technology, coupled with a demand for high-technology goods and commercial value. This generates a trade deficit and an unfavorable environment for future sustainability.

The generation of Mexican varieties of sugarcane began in 1930, peaked in the 1970s, and in 1990 began to decline (Flores, 2001). Efforts coordinated by the National Chamber for the Sugar and Alcohol Industries (Cámara Nacional de las Industrias Azucarera y Alcoholera, CNIAA), the Center for Research and Development of Sugarcane (Centro de Investigación y Desarrollo de la Caña de Azúcar, CIDCA), the Secretariat for Agriculture, Livestock, Rural Development, Fisheries and Food (Secretaría de Agricultura, Ganadería, Desarrollo Rural, Pesca y Alimentación, SAGARPA), the National Committee for the Sustainable Development of Sugarcane (Comité Nacional para el Desarrollo Sustentable de la Caña de Azúcar, CONADESUCA) and the sugarcane organizations National Confederation of Rural Holders (Confederación Nacional de Propietarios Rurales, CNPR) and the National Confederation of Farmers (Confederación Nacional Campesina, CNC), have maintained the agribusiness and are fundamental players for the increases observed to date.

Mexico is currently the sixth largest producer of sugar and sugarcane (FAOSTAT, 2013; ZAFRANET, 2013) which is not purely for export and the activity is based on domestic consumption (Aguilar-Rivera, 2012). The 2012/2013 harvest was conducted over an area of approximately 780000 ha with 55 refineries in operation, and a production of 61.5 million tons of cane and a total of 6.7 million tons of sugar (CNPR, 2013; CONADESUCA, 2013). Apparent domestic consumption is more than 5 million tons of sugar per year with an annual per capita consumption of $47 \mathrm{~kg}$ (Aguilar-Rivera, 2012). Today, this agribusiness has an economic impact of approximately 2591 million dollars, economically and socially impacting over 3 million Mexicans (Secretaría de Economía, 2012). In 2011, Mexico contributed 3\% of the global sugarcane production (FAOSTAT, 2013).

In Mexico, the cultivation of sugarcane is concentrated in six regions (Figure 1): Northwest (state of Sinaloa), Pacific (states of Nayarit, Jalisco, Michoacán and Colima), Center (states of Puebla and Morelos), Northeast (states of Tamaulipas and San Luis Potosí), Gulf (states of Veracruz, Oaxaca and Tabasco) and South (states of Chiapas, Campeche and Quintana Roo) (CONADESUCA, 2013). The average yield of sugarcane was $66.10 \mathrm{t} \mathrm{ha}^{-1}$ for the $2010 / 2011$ harvest, $65.87 \mathrm{t} \mathrm{ha}^{-1}$ for the 2011/2012 harvest and $78.74 \mathrm{t} \mathrm{ha}^{-1}$ for the 2012/2013 harvest, 
resulting in an average national yield of $70.2 \mathrm{t} \mathrm{ha}^{-1}$ for the last three harvest periods. Sugarcane harvesting in Mexico occurs over eight months, beginning in November and ending in June (Figure 1).

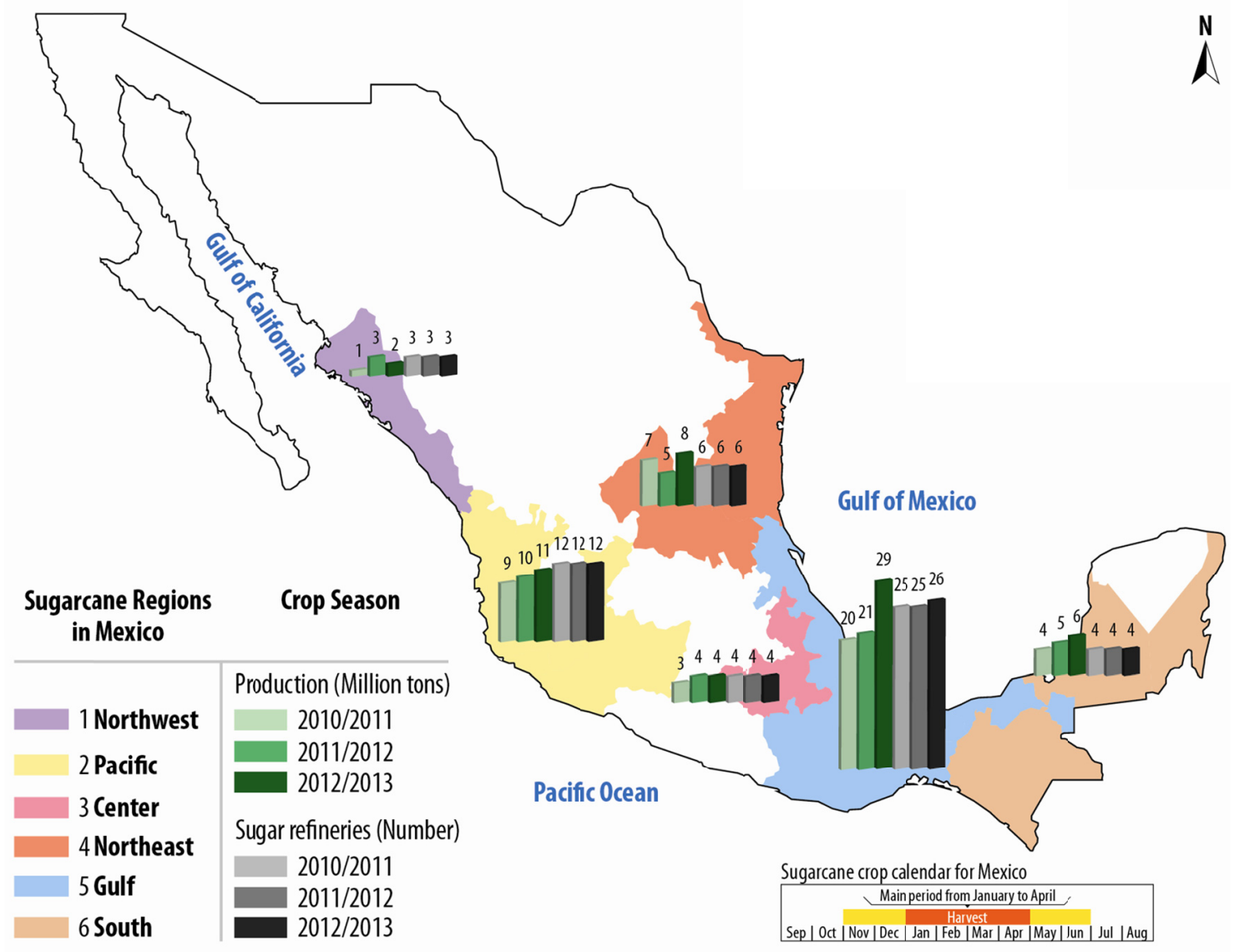

Figure 1. Mexican states where sugarcane is cultivated. Green columns represent sugarcane harvests in millions of tons, while the number of sugar refineries that operated are depicted by gray columns. Both indicators are shown for the last three harvest cycles: 2010/2011, 2011/2012 and 2012/2013. The six regions containing the 15 states where sugarcane is cultivated are shown in different colors (Sources: Blackaller, 2011; CNIAA, 2013; CONADESUCA, 2012, 2013)

The absence of a national model for diversification and management of information and knowledge on the subject are the primary obstacles to the consolidation of a sustainable, efficient and competitive sugarcane industry (Aguilar-Rivera, Galindo-Mendoza, Fortanelli-Martínez, \& Contreras-Servín, 2011). This represents a great challenge, requiring the development of appropriate strategies to tap the full potential of sugarcane and the growth of internal and external markets, and will be affected by increased oil prices, and the appearance and demand for alternative sweeteners and biofuels which will increase pressure on the production systems, forcing them to seek innovative, sustainable and socially responsible alternatives for this value-chain (Gómez-Merino \& Hernández-Anguiano, 2013). Although the last decade has seen a substantial increase in sugarcane production, as in 2012 when the area sown increased by $10 \%$ over the previous year, and similar growth is expected during the coming years (CNPR, 2013), there are still significant lags in the entire value-chain, ranging from the low education of producers and the low efficiency in government programs that support them, to an obsolete industrial infrastructure, inadequate regulation and a disadvantageous commercial system.

\section{The Sugarcane Production System in Mexico}

The sugarcane production system in Mexico is defined by many interacting economic, environmental and agronomic factors within each sugarcane region, as well as their magnitude and intensity. 


\subsection{Socio-Economic Factors}

According to estimates (Secretaría de Economía, 2012), sugarcane production generates dividends of approximately 2591 million dollars (Table 1) and positively impacts the regions producing it, leading to a reduced rate of marginalization predominantly at the municipal level by decreasing the lags in income, increasing access to education, and providing more adequate housing and basic services (CONAPO, 2010a) (Figure 2).

Table 1. Economic and production indicators for sugarcane-producing states in Mexico by 2012

\begin{tabular}{ccccccc}
\hline State & $\begin{array}{c}\text { Area planted } \\
(\text { ha })\end{array}$ & $\begin{array}{c}\text { Area harvested } \\
(\text { ha })\end{array}$ & $\begin{array}{c}\text { Production } \\
(\mathrm{t})\end{array}$ & $\begin{array}{c}\text { Yield } \\
\left(\mathrm{t} \mathrm{ha}^{-1}\right)\end{array}$ & $\begin{array}{c}\text { Price per ton } \\
(\mathrm{US} \$)\end{array}$ & $\begin{array}{c}\text { Production value } \\
(\text { millions of US\$) }\end{array}$ \\
\hline Campeche & 10801.92 & 9048.36 & 426811.14 & 47.17 & 51.66 & 22.05 \\
Colima & 14449.25 & 14444.25 & 1368014.92 & 94.71 & 53.80 & 73.60 \\
Chiapas & 30350.14 & 30350.14 & 2819528.01 & 92.90 & 53.74 & 151.53 \\
Jalisco & 80119.72 & 75820.72 & 6254451.19 & 82.49 & 49.70 & 310.84 \\
Michoacán & 14522.75 & 14515.75 & 1188985.08 & 81.91 & 48.96 & 58.21 \\
Morelos & 16275.00 & 16275.00 & 1927773.75 & 118.45 & 61.18 & 117.94 \\
Nayarit & 33441.34 & 32596.44 & 2247524.54 & 68.95 & 57.31 & 128.80 \\
Oaxaca & 67989.14 & 62014.19 & 3482716.91 & 56.16 & 50.29 & 175.14 \\
Puebla & 12137.65 & 12137.65 & 1777437.47 & 146.44 & 55.38 & 98.44 \\
Quintana Roo & 28421.00 & 28421.00 & 1682523.20 & 59.20 & 35.86 & 60.34 \\
San Luis Potosí & 64158.00 & 64001.00 & 2529319.52 & 39.52 & 51.07 & 129.18 \\
Sinaloa & 23586.48 & 20418.54 & 1777638.09 & 87.06 & 50.25 & 89.32 \\
Tabasco & 29112.00 & 28705.00 & 1780571.15 & 62.03 & 47.46 & 84.50 \\
Tamaulipas & 62038.00 & 55841.00 & 3571590.36 & 63.96 & 54.54 & 194.78 \\
Veracruz & 289840.32 & 270537.64 & 18112495.00 & 66.95 & 49.47 & 896.02 \\
National & 777242.71 & 735126.68 & 50964485.13 & 69.33 & 50.85 & 2591.57 \\
\hline
\end{tabular}

Source: SIAP, 2012.

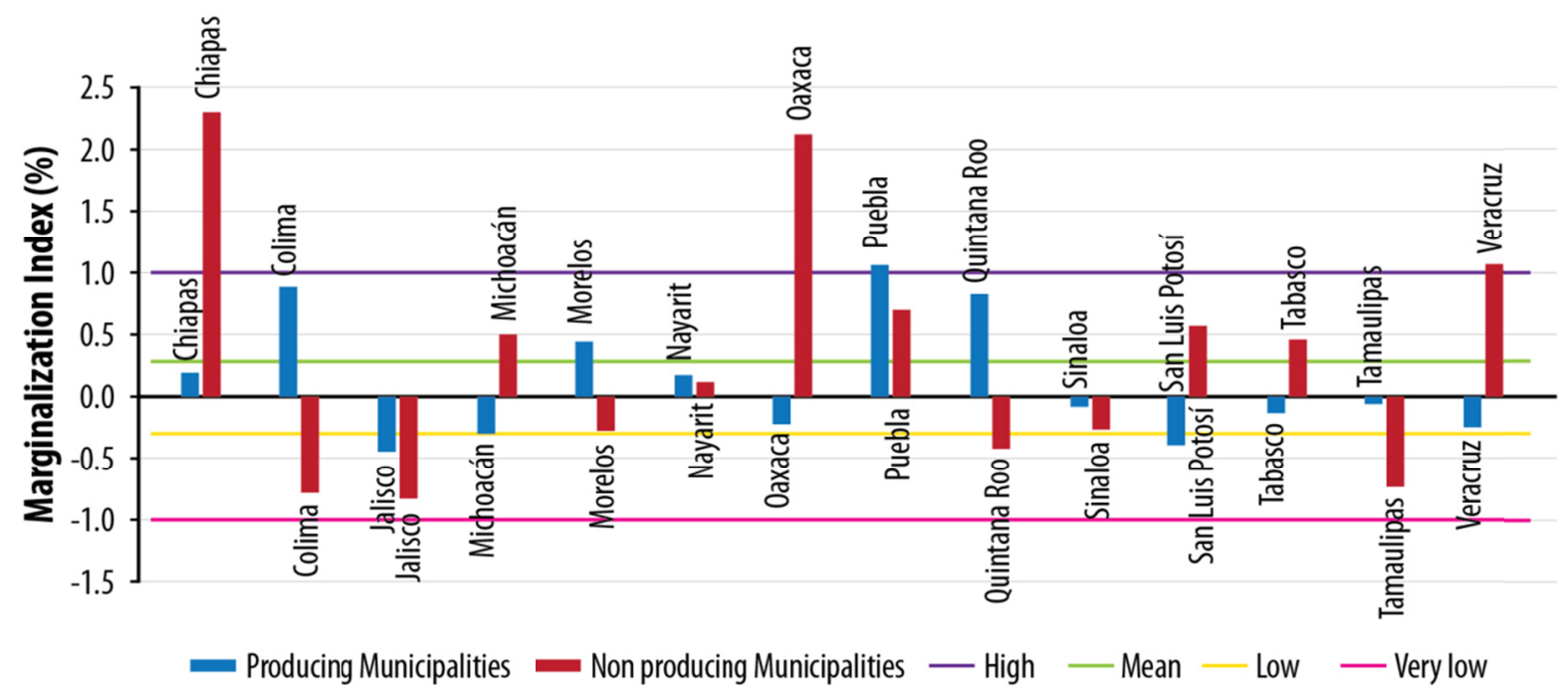

Figure 2. Marginalization indices for sugarcane producing (in blue) and non-producing municipalities (in red) among the 15 sugarcane-producing states in Mexico (Sources: CONAPO, 2010a, b; Secretaría de Economía, 2012) 
Municipalities without sugarcane production are smaller than those producing sugarcane, with $80 \%$ of their populations living in towns with fewer than 5000 inhabitants, $60.7 \%$ of the inhabitants receiving less than two minimum wages and $23.8 \%$ without basic education (Secretaría de Economía, 2012), which puts them at a disadvantage. The more than 220 municipalities where sugarcane is produced are home to more than 12 million people, and their average contribution to national added value is 7.1\% (INEGI, 2012; CONAPO, 2010a).

The diversification of the sugarcane agribusiness has been suggested as a strategy to increase profitability. However, according to Aguilar-Rivera (2012), such diversification could affect the supply of sugar and its market price due to competition for raw material (sugarcane) through simple fluctuation in supply and demand. Due to conflicts of interest, lack of strategic planning, dialogue, and consultation between the groups involved, diversification of this agribusiness has been only in political discourse. As such, alcohol production, for example, has fallen by roughly $80 \%$, from 67 thousand liters of ethanol to only 14 thousand in the last decade, with only three refineries operating distilleries since 2010 (Secretaría de Economía, 2012).

Rather than relying on efficient and sustainable use of resources for production, sugarcane field dynamics respond to increases in harvested area, with a slight tendency for increases in yields. This behavior is a consequence of an unfavorable ratio between primary producers and the industry, as well as excessive government regulation that discourages competitiveness in the fields and factories. In addition, imports of high fructose corn syrup (HFCS) and other non-caloric sweeteners produced by high technology compete and displace domestic sugar production (Aguilar-Rivera et al., 2012; Secretaría de Economía, 2012). Indeed, in 2013, Mexico imported nearly 1300 thousand tons of HFCS from the USA (USDA, 2014), and the domestic market for this sweetener increases annually. In a recent study, Goran, Ulijaszek, and Ventura (2013) reported that countries with higher availability of HFCS have higher prevalence of type 2 diabetes. As in Mexico, there is a high prevalence of diabetes (14\%), which is the leading cause of death in women and second in men (Sosa-Rubí, Galárraga, \& López-Ridaura, 2009); HFCS poses a serious public health problem that must be properly managed.

Another socioeconomic factor determining the behavior of the system is land tenure. Of the total acreage devoted to this crop, $76.3 \%$ occurs in areas of 5 ha or less in suburbs and rural communities, while $18.8 \%$ is distributed in areas between 5.1 and 10 ha, and only $4.9 \%$ occurs in areas larger than 10 ha (Secretaría de Economía, 2012; INEGI, 2012). According to Pérez-Zamorano (2007) and Singelmann (2003), sugarcane small-holders and common lands, locally known as ejidos, and other socio-political phenomena in the field act as brakes on the sugar industry, separating land and capital, the two most important factors in terms of production agriculture and social welfare. Strategies such as digitizing sugarcane fields to improve agricultural precision have been undertaken by SAGARPA under the National Program for the Sugarcane Agroindustry (Programa Nacional de la Agroindustria de la Caña de Azúcar, PRONAC) and have provided important technological tools, but a joint effort to comprehensively address the multifaceted problems affecting this value-chain is still required, particularly in terms of land tenure and small-holders.

\subsection{Environmental Factors}

In Mexico, sugarcane production systems are located along the coasts of the Pacific Ocean and the Gulf of Mexico, in valleys of the Altiplano (high plateau), to southern Quintana Roo, where climates are varied. Historical records show $90 \%$ of the minimum monthly temperatures in sugarcane areas range from $10^{\circ} \mathrm{C}$ to $20^{\circ} \mathrm{C}$ from November to March. In contrast, the average monthly maximum temperature lies between $20^{\circ} \mathrm{C}$ and $30^{\circ} \mathrm{C}$ from December to February, increasing to more than $30^{\circ} \mathrm{C}$ between April and September (COLPOS, 2008; CONADESUDA, 2012).

Regarding irrigation, production is distributed with $62 \%$ in rainfed areas and the remaining $38 \%$ in irrigated areas (CONADESUCA, 2011a), with the average water consumption varying from 5.48 to $6.84 \mathrm{~mm}$ per day, which equates to 2000-2500 mm of rainfall per year. According to Moyer (2010), Mexico is the second-most vulnerable country to the effects of global climate change, with agricultural production possibly decreasing by more than $25 \%$ by 2080 if the country does not develop efficient strategies to adapt to this phenomenon. Growth in irrigation infrastructure is therefore critical to the success of this activity, as sugarcane cultivation is one of the most demanding for water and fertilizer. Advances in biotechnology, nanotechnology and precision agriculture are also required and Mexican institutions are making good progress in this regard.

Land for sugarcane production in Mexico has physical and chemical characteristics generally suitable for cultivation (COLPOS, 2008). Soils in cultivated areas are mainly classified as eutric fluvisol, vertisol eutric, cambisol endogleyic, eutric and chromic rendzic, and luvisol leptosol gleyic (Palma-López, 2009). The variation of some physical and chemical soil indicators are shown in Appendix A Table S1, which have direct or indirect relationships with the water catchment areas (rain and water storage capacity of the soil) (COLPOS, 2008). 
Approximately $70 \%$ of the soils in sugarcane cultivation areas have nitrogen concentrations between 10 and $20 \mathrm{~kg}$ $\mathrm{ha}^{-1}$, thus requiring the application of nitrogen fertilizers, $27.2 \%$ have phosphorous concentrations above $30 \mathrm{~kg}$ $\mathrm{ha}^{-1}$, and $74 \%$ show potassium content higher than $160 \mathrm{~kg} \mathrm{ha}^{-1}$. Most of the soils dedicated to sugarcane cultivation (68.3\%) show calcium levels between 2500 and $10000 \mathrm{~kg} \mathrm{ha}^{-1}$, whereas magnesium ranges from 500 to over 1000 $\mathrm{kg} \mathrm{ha}^{-1}$ on $65 \%$ of sugarcane land (detailed information in Appendix A Table S2) (COLPOS, 2008). Concentrations of the micro-nutrients $\mathrm{Fe}$ and $\mathrm{Mn}$ are high in most cases, even in areas with alkaline and calcareous conditions. Copper concentrations are mostly between 0.5 and $3 \mathrm{mg} \mathrm{kg}^{-1}$ of soil, while zinc is most often found in concentrations below $1 \mathrm{mg} \mathrm{kg}^{-1}$ of soil (COLPOS, 2008) (detailed information in Appendix A Table S3).

The general climate and soil characteristics in sugarcane producing areas indicate that conditions are favorable for crop development, and permit the identification of advantages and limitations (see Appendix A Table S4 for details). These data are crucial for making predictions about development, adaptability and crop production, as well as looking for new farmland. A projection for the areas with the greatest potential for expansion of sugarcane cultivation in Mexico shows that the current area devoted to this crop could grow to 5 million ha (with approximately 500 thousand ha showing high potential and 4.5 million ha with average potential) (SAGARPA, 2009).

\subsection{Agronomic Factors}

The National Program for High Sugarcane Profitability (Programa Nacional para la Alta Rentabilidad de la Caña de Azúcar, PRONAR, 2009) estimates that the low average productivity obtained over the last decade is due to a scarce use of emerging technology for water and soil analysis, as well as an inefficient soil management program, the lack of an effective national program for the generation and use of new varieties (efforts are made independently by each refinery), the absence of certified seed production systems, no national program coordinating the management and control of diseases, pests and weeds, and harvest management without quality controls. In addition, sugarcane in Mexico is grown in seven-year cycles, and the area planted is composed of $13 \%$ new plantings ( 1.5 years in age), $15 \%$ ratoons called soca (second crop from the same planting at 2.5 years old) and $72 \%$ of the ratoons known as resoca (third crop from the first planting, $>2.5$ years of age) (Aguilar-Rivera et al., 2012), implying lower productivity for older plantations. Faced with this problem, the objective of PRONAR (2009) is to increase the profitability and competitiveness of Mexican sugarcane fields using the following ten steps: 1. Empowerment of farmers and smallholders; 2. Diagnoses limiting factors (water and soil); 3. Systematize tillage and soil preparation; 4. Schedule date and densities for seeding; 5. Select adequate seeds and varieties; 6 . Apply balanced fertilization; 7. Manage water and wastewater properly; 8. Integrated management of pests and weeds; 9 . Prepare systems for harvesting; and 10. Increase the capacity for mechanized harvesting. Although much to date has yet to be improved, PRONAR has facilitated the growth of production and productivity of sugarcane from its inception, as reflected in field and refinery yields.

\subsubsection{Pest Management}

The most important pests of sugarcane in Mexico are grass spittlebugs (various genera), stem-borers (various genera) and cane rats (various genera), which are distributed in all sugarcane cultivation areas (Flores, 2007). Spittlebugs cause losses ranging between 5 and $20 \mathrm{tha}^{-1}$ (CNPR, 2004). Methods of control include biological with the application of the fungus Metarhizium anisopliae, preparatory soil tillage, and chemical control (Toriello et al., 2008).

Regarding stem-borers, it is estimated that for every $1 \%$ increase in pest intensity, sugar losses are $5.8 \mathrm{~kg} \mathrm{ha}^{-1}$ and with a decrease of 2 to $50 \%$ in yield (Aday, Barroso, \& Izquierdo, 2003; Arredondo-Bernal \& Rodríguez del Bosque, 2008), which also increases the incidence of fungal infections and contamination of juice (Hernández-Velázquez, Lina-García, Obregón-Barboza, Trejo-Loyo, \& Peña-Chora, 2012). Integrated control of this pest consists of eliminating hosts in cultivation fields, preparatory soil tillage, and reducing insecticide use (Sánchez, 2005). Biological control includes the use of parasitoids and predators as natural enemies, such as: Trichogramma atopovirilia, Chelonus sonorensis, Apanteles diatrea, Cotesia flavipes and Billaea claripalpis (formerly Paratheresia claripalpis). As well, applications of the fungi Metarhizium anisopliae and Beauveria bassiana have been successful in managing pest populations (Arredondo-Bernal \& Rodríguez del Bosque, 2008).

Cane rats are the most destructive pests of sugarcane plantations in the country, attacking approximately $30 \%$ of the cultivated area (Flores, 2007; CONADESUCA, 2013; Vásquez-López, Lorenzo-Monterrubio, \& Bolaños-Citalan, 2013). It has been estimated that for every $1 \%$ of affected stems there is a reduction of $500 \mathrm{~kg} \mathrm{ha}^{-1}$ of cane sugar. Additionally, there is an estimated loss of $2.2 \mathrm{~kg}$ per metric ton of sugar in the refineries for every $1 \%$ increase in damage intensity (Márquez, 2002; Flores, 2007). Methods of rodent control include cultural (based on modifying cane rat habitat using simple practices of weed control plots, dikes and irrigation canals) and 
biological, using birds of prey such as Accipiter spp., Buteo spp., Aquila chrysaetos, and snakes such as Boa constrictor, Conopsis spp., and Crotalus spp., achieving a 50\% reduction in damage (Cervantes \& Ballesteros-Barrera, 2012; Vásquez-López et al., 2013).

The primary pests, parasitoids and predators of insects in Mexican sugarcane cultivation are listed in Appendix A Table S5, while plant protection products authorized for control appear in Appendix A Table S8.

\subsubsection{Disease Management}

In Mexico, 55 plant diseases have been reported, 22 from parasites and 33 from non-parasites (Chinea-Martín \& Milanés-Ramos, 2006). Among the most important diseases are rust, smut, mosaic and scald (CONADESUCA, 2011b). In addition to the genetic resistance provided by sugarcane varieties, use of pathogen-free seed has been implemented to prevent the spread of diseases. Heat treatments and tissue culture are disinfection methods that ensure plant health and seed cane. Although disease control in commercial sugarcane fields in Mexico is not a common practice, with the recent detection of orange rust [Puccinia kuehnii (W. Krüger) E. J. Butler] in the country, the National Service of Health, Food Safety and Quality (Servicio Nacional de Sanidad, Inocuidad y Calidad Agroalimentaria, SENASICA) has registered various fungal control products (SENASICA, 2011) (Rebollar-Alviter, Sánchez-Pale, \& Silva-Rojas, 2012). The major diseases of sugarcane in Mexico are listed in Appendix A Table S6.

\subsubsection{Weed Management}

Control of unwanted vegetation or weeds is an essential practice in the early stages of sugarcane development, because if not controlled in a timely fashion, they can cause losses in crop productivity between 10 and $84 \%$ (Cruz, 2009). The most harmful weed species belong to the families Poaceae and Cyperaceae (order Poales), but species of the genus Ipomoea spp. (order Solanales; family Convolvulaceae) also interfere with sugarcane plant development (CONABIO, 2012). The use of herbicides (chemical control) is the most common form of weed control in most cultivation areas around the world. In Mexico, the most widely used herbicides are ametrine and diuron, which are recommended for postemergence application and have a residuality of one to two months, depending on moisture and soil type (Esqueda, 1999). A list of major weeds found in sugarcane cultivation areas in Mexico appears in Appendix A Table S7, whereas authorized control products that are registered with SENASICA (SENASICA, 2011) and permitted for use in the cultivation of sugarcane in Mexico are listed in Appendix A Table S8. The use of different organisms and natural active substances for the management and control of sugarcane pests are also being investigated (Arredondo-Bernal \& Rodríguez del Bosque, 2008; CONABIO, 2012; Salgado-García et al., 2013).

\section{Structure of the Mexican Sugar Agribusiness System}

The Mexican sugarcane production system is a mosaic of cultural, social, political, economic, technical and educational factors that limit and slow rural development and industrial sugarcane production. To solve this problem, it is necessary to begin with the primary sector, the field, which is characterized by low income and yield per unit of production; poor agronomic practices; small cultivation areas ( 3 ha per producer on average); resistance to technological change because of cultural values and beliefs; complex social relationships; lack of enforcement of regulations and phytosanitary protocols; and organizational structures that maintain the damaging cycle of low production - low income - poverty - social, economic, environmental and political marginalization (Aguilar-Rivera, 2013). A recent analysis, however, shows that there are three determinants of sugarcane productivity: field performance and agribusiness, credit and irrigation, which contrast with the prioritization of needs for research-development-innovation that producers have been proposing: generation of new varieties, pest and disease control (CONADESUCA, 2013).

Currently there is a certain dynamic of transformation and modernization, not only to make this activity more productive, but also to address the challenges of climate change and globalization, including the use of new technologies, machinery and modern equipment, and considering environmental, employment and social sustainability indicators as well. However, these initiatives are erratic and inconsistent over time, restricting the consolidation of global competitiveness of the agribusiness system, which in terms of creating value is the second largest in the country, just after the maize value-chain (Aguilar-Rivera et al., 2012).

In terms of operational structure, the 55 sugar refineries currently operating in Mexico belong to 14 industrial groups, while six refineries are independent (for details see Appendix A Table S9) (MAM, 2013). Of the total, $76 \%$ of the sugar is in the hands of private business, while the remaining $24 \%$ is under federal control.

Sugar productivity is highly variable and generally uncompetitive. For example, in the last harvest (2012/2013) the average supply ranged from $53.8 \mathrm{tha}^{-1}$ in Aszuremex Tenosique (Tabasco) to $125.8 \mathrm{t} \mathrm{ha}^{-1}$ in Tamazula (Jalisco), 
yielding a national average of $78.7 \mathrm{t} \mathrm{ha}^{-1}$. In the previous harvest (2011/2012), the lowest yield was $35.9 \mathrm{t} \mathrm{ha}^{-1}$ from the refinery in Alianza Popular (San Luis Potosí) and the highest was $121.4 \mathrm{t} \mathrm{ha}^{-1}$ from Atencingo (Puebla), yielding a national average of $65.8 \mathrm{tha}^{-1}$ (CONADESICA, 2012, 2013) (a detailed analysis of the past 30 years is discussed later). This dichotomy between low and high productivity is due to differences in the size and capacity of the refineries, refinery age and level of technology, with a predominance of medium and small refineries, having an average age of 77 years, with obsolete and inefficient technologies, which increase production costs and decrease productivity. In addition, this value-chain is facing serious problems from environmental impact and is being severely criticized because it occupies large tracts of fertile land that could be used for the production of basic grains, accelerates deforestation and land degradation, forms implicit monocultures, contaminates or pollutes soils, surface and groundwater and air through the indiscriminate use of fertilizers, pesticides, herbicides, molasses, other waste products and the burning of cane fields prior to harvest (Aguilar-Rivera et al., 2012). Also common in this system are low seasonal wages, excessive working hours under deplorable conditions, and the employment of children and women in risky work. In fact, in Mexico there is no systematized project that has had sufficient time to develop human capacity at any stage of the value-chain. On average, $71 \%$ of the rural producers have only a basic education (six years of primary school) and 18\% cannot read or write (Aguilar-Rivera et al., 2011), which further hinders constructive change.

\section{Legislation and Organizations in the Mexican Sugar Industry}

The legal framework supporting and regulating the sugar industry in Mexico is complex and extensive, and consists of the following contracts, laws and agreements: Ley de Desarrollo Rural Sustentable, Ley de Desarrollo Sustentable de la Caña de Azúcar, Programa Nacional de la Agroindustria Cañera 2007-2012, Ley de Promoción y Desarrollo de los Bioenergéticos, Ley para el Aprovechamiento de Energías Renovables y el Financiamiento de la Transición Energética, Contrato Ley de la Agroindustria Azucarera y Alcoholera, Ley del Seguro Social, Ley Federal del Trabajo and international free commerce (Blackaller, 2011). Derivatives of the Ley de Desarrollo Sustentable de la Caña de Azúcar (LDSCA, 2005), the National Program for the Sugarcane Agroindustry (PRONAC, 2007) and the Acuerdo para la Modernización de la Agroindustria de la Caña de Azúcar are intended to provide greater certainty for this national industry for the buying and selling, planting, cultivating, harvesting, delivering and receiving of sugarcane (Blackaller, 2011; CONADESUCA, 2013).

Sugar industry organizations perform specific functions that benefit this value-chain, and include: CONADESUCA, CNIAA, the National Association of Sugar Companies (Asociación Nacional de Empresas Azucareras, A.C., ANEA), the Mexican Association of Sugar Technicians (Asociación de Técnicos Azucareros de México, A.C., ATAM), the Mexican Union of Sugarcane Workers (Sindicato de Trabajadores de la Industria Azucarera y Similares de la República Mexicana, STIASRM), CNPR, the National Union of Sugarcane Growers (Unión Nacional de Cañeros, UNC), the National Union of Sugarcane Producers (Unión Nacional de Productores de Caña de Azúcar, UNPCA), and the Mexican Regional Workers Confederation (Confederación Regional Obrera Mexicana, CROM).

\section{Agricultural Insurance for Sugarcane in Mexico}

As a consequence of climate change, drought in Mexico causes $80 \%$ of the agricultural losses, while severe weather (e.g. storms, cyclones and hurricanes) contribute 18\% of the damage (AGROASEMEX, 2006). In 2012, nearly 12 million hectares of national agriculture (54\% of the cultivated area in the country) benefited from some form of insurance (SIAP, 2013). In Mexico, $80 \%$ of the insurance is concentrated on only four crops: corn, sorghum, wheat and sugarcane, and of this amount, $76.4 \%$ are operated by government insurance funds and $23.6 \%$ by private insurers.

Insurance for sugarcane represents $14 \%$ of the total agricultural area secured in Mexico, and $91.2 \%$ of the insurance is provided by private companies (AGROASEMEX, 2013). The 14 thousand hectares of sugarcane affected each year represent losses of 15.1 million dollars annually (Rivera, 2012). Currently, of the more than 780 000 ha planted with sugarcane in Mexico, 321000 ha are insured, which represents $41 \%$ of the total area planted with sugarcane (AGROASEMEX, 2013).

\section{Historical Productivity of Sugarcane and Sugar in Mexico}

The Mexican sugar industry has had irregular development over the last thirty years, and the number of refineries has declined from 67 in 1980 to 55 at the close of 2013. In contrast, during this same period (1980-2013), the area planted increased by $39 \%$, productivity of supply areas grew by $17 \%$, factory efficiency improved by $19 \%$, and sugar production grew by $62 \%$ (Figures 3,4 ). The relative gains were due to factors related with government subsidies ( $8 \%$ of the total national agricultural subsidies), and some recent efforts to increase productivity through 
support for training, digitization and systematization of processes, and modernization of the production equipment for at least $40 \%$ of the refineries and their supply areas.

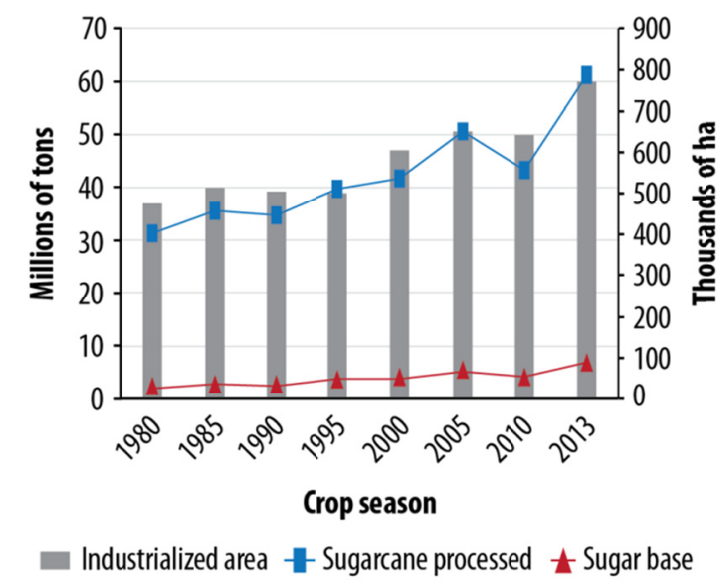

Figure 3. Total sugarcane production and surface area planted during the last three decades in Mexico (Source: MAM, 2013)

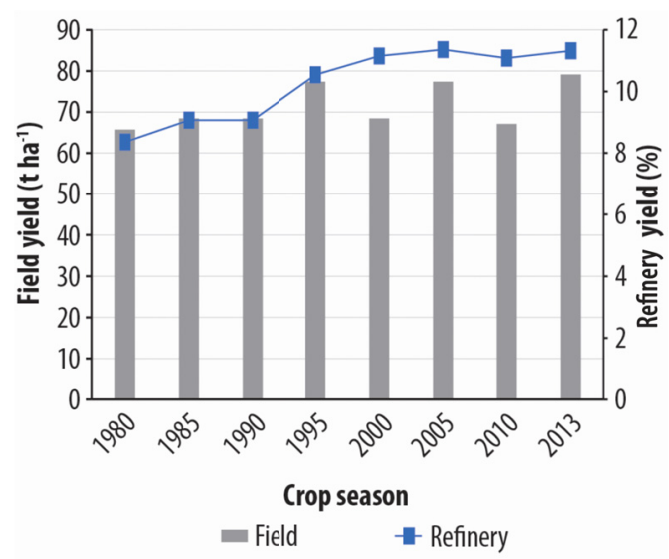

Figure 4. Sugarcane production in the fields and factories during the last three decades in Mexico (Source: MAM, 2013)

Despite this upward trend in absolute terms, and accounting for figures, improved productivity indicators are modest. For example, while in Mexico the average field harvest during the last three harvest periods (2010/2011, 2011/2012 and 2012/2013) was $70.2 \mathrm{t} \mathrm{ha}^{-1}$, in other Latin American countries such as Guatemala, Colombia and Peru, yields exceeded $100 \mathrm{t} \mathrm{ha}^{-1}$ (Secretaría de Economía, 2012). As for Mexico, these increases have been based largely on government subsidies and increased plantings, rather than in process efficiency.

\section{Government Support for Sugarcane Research}

The technology used in the fields and refineries is mostly provided by other countries, and investment in scientific research, technological development and innovation $(\mathrm{R}+\mathrm{D}+\mathrm{I})$ is sparse and erratic because Mexico spends only $0.49 \%$ of its GDP on $\mathrm{R}+\mathrm{D}+\mathrm{I}$, with only $\$ 200$ million dollars invested annually on agricultural research (CONACyT, 2012; OECD, 2013). Private resources for scientific research in this value-chain are limited, while the government only in the last three years (2011-2013) had a spike of \$14.4 million dollars, and a total of \$20.8 million dollars allocated between 2003 and 2013 (Figure 5). 


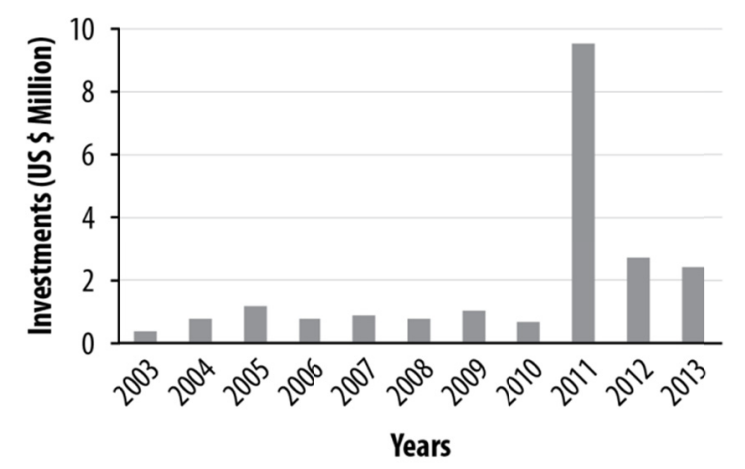

Figure 5. Government funds destined for sugarcane research in Mexico during 2003-2013 (Sources: CIDCA, 2013; SNITT, 2013)

In Mexico, less than $1 \%$ of the sugarcane cultivation area is dedicated to scientific experimentation and there is only one breeding program with very uncertain economic resources (Quintero-Núñez, 2012). This program is supported by government and producers through CONADESECA, which emphasizes the main priorities of innovation and technology transfer as: generation of new varieties, management and control of pests and diseases, and agricultural components of technology in irrigation and fertilization according to the demand of the Committee for Sugarcane Production and Quality (Comités de Producción y Calidad Cañera, CPCC) (CONADESUCA, 2011b). This prioritization, however, does not attend to important issues such as adaptation to climate change and efficient water use, topics of primary importance to Mexico due to the vulnerability of agricultural regions (Moyer, 2010).

Importantly, in 2013, the federal government, through SAGARPA, approved an emergency program in the amount of $\$ 115$ million dollars for sugarcane production, whose objective is to enhance sugarcane productivity in the country (Blackaller, 2013).

\section{Genetic Improvement of Sugarcane in Mexico}

The sugarcane genetic improvement program represents a coordinated effort among eleven Regional Experimental Stations (Campos Experimentales Regionales, CERs), as well as quarantine and hybridization stations (Figure 6). The Hybridization Station is located in Tapachula, Chiapas (housed within CIDCA), whose geographical location provides excellent natural conditions to obtain Fuzz (seeds) of high quality and viability. There is a germplasm bank housing 2768 varieties, of which 250 are classified by sex and can be found in the Plant Breeding Center (Banco de Cruzamientos), crosses which are conducted every year for different agroecological zones in Mexico and for international commitments (CIDCA, 2013). The National Sugarcane Quarantine Station (Estación Nacional Cuarentenaria de la Caña de Azúcar, ENCCA) is located in Tizimín, Yucatán, where genetic material received from other countries is evaluated for 18 months to confirm that it is not contaminated. This clean material is sent to different CERs in the country and to CIDCA. The CIDCA Germplasm Bank enters only those genotypes that present outstanding characteristics as parent stock to continue the hybridization program (Flores, 2012). 


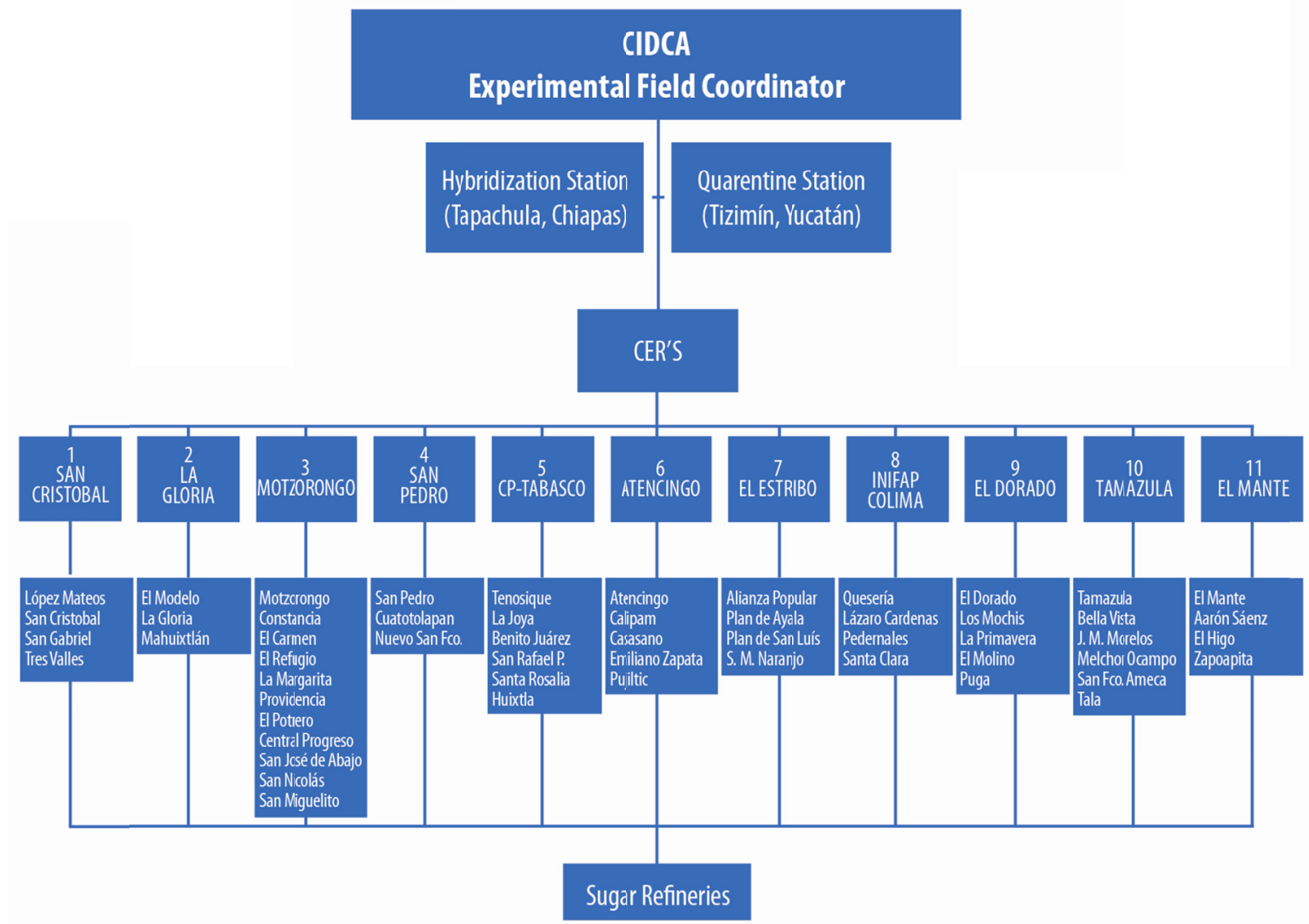

Figure 6. Coordination of the breeding and selection program for sugarcane varieties in Mexico. CIDCA contains many Regional Experimental Centers (Centros Experimentales Regionales, CERs) and each CER serves a number of sugar refineries

The selection process consists of the following phases: seedling, row, stump, plot, Multiplication I, adaptability test, Multiplication II, agroindustrial evaluation, Multiplication III, semi-commercial and seed testing. This process makes available one to four varieties every 14-16 years (for details see Appendix A Table S10) (IMPA, 1983; Flores, 2001).

\subsection{Current Developments in Genetic Improvement of Sugarcane in Mexico}

Since 1952, the work performed in the Hybridization Station in CIDCA has allowed for the release of 150 Mexican varieties, which occupy $55 \%$ of the sown area in the country; the remaining $45 \%$ is planted with foreign varieties from the National Program for Exchange and Import of Sugarcane Varieties maintained by CNIAA (CIDCA, 2013). The best performing Mexican varieties are: Mex 69-290, Mex 79-431, ITV 92-1424, Mex 68-P-23, Mex 57-473, ATEMEX 96-40, Mex 69-749, Mex 68-1345, Mex 55-32, Mex 73-1240 and Mex 80-1410, while the most important foreign varieties are: CP 72-2086, RD 75-11, My 55-14, NCo 310, SP 70-1284, Co 997, L 60-14 and CP 44-101 (MAM, 2013). Thanks to the genetic improvement program, sugarcane production and productivity has been increasing and it is estimated that yields have grown annually by $0.4 \%$. However, compared to the yield increases in Brazil, which have reached 1.5\% per annum (Waclawovsky et al., 2010), the gains in Mexico are modest. Moreover, in 1980, nine varieties occupied 70\% of the cultivated area, while in 2013 this number was reduced to three varieties (Mex 69-290, Mex 79-431 and CP 72-2086) that occupy the same percentage of acreage (Figure 7). This indicates that the improvement program in the country needs to expand its genetic base, given the tendency toward greater homogeneity of the materials that make the system vulnerable to abiotic and biotic factors (Alejandre-Rosas, Galindo-Tovar, \& Lee-Espinoza, 2010; González-Jiménez, Valdez-Balero, Gómez-Merino, Silva-Rojas, Pérez-Flores, \& Ortiz-García, 2011). 


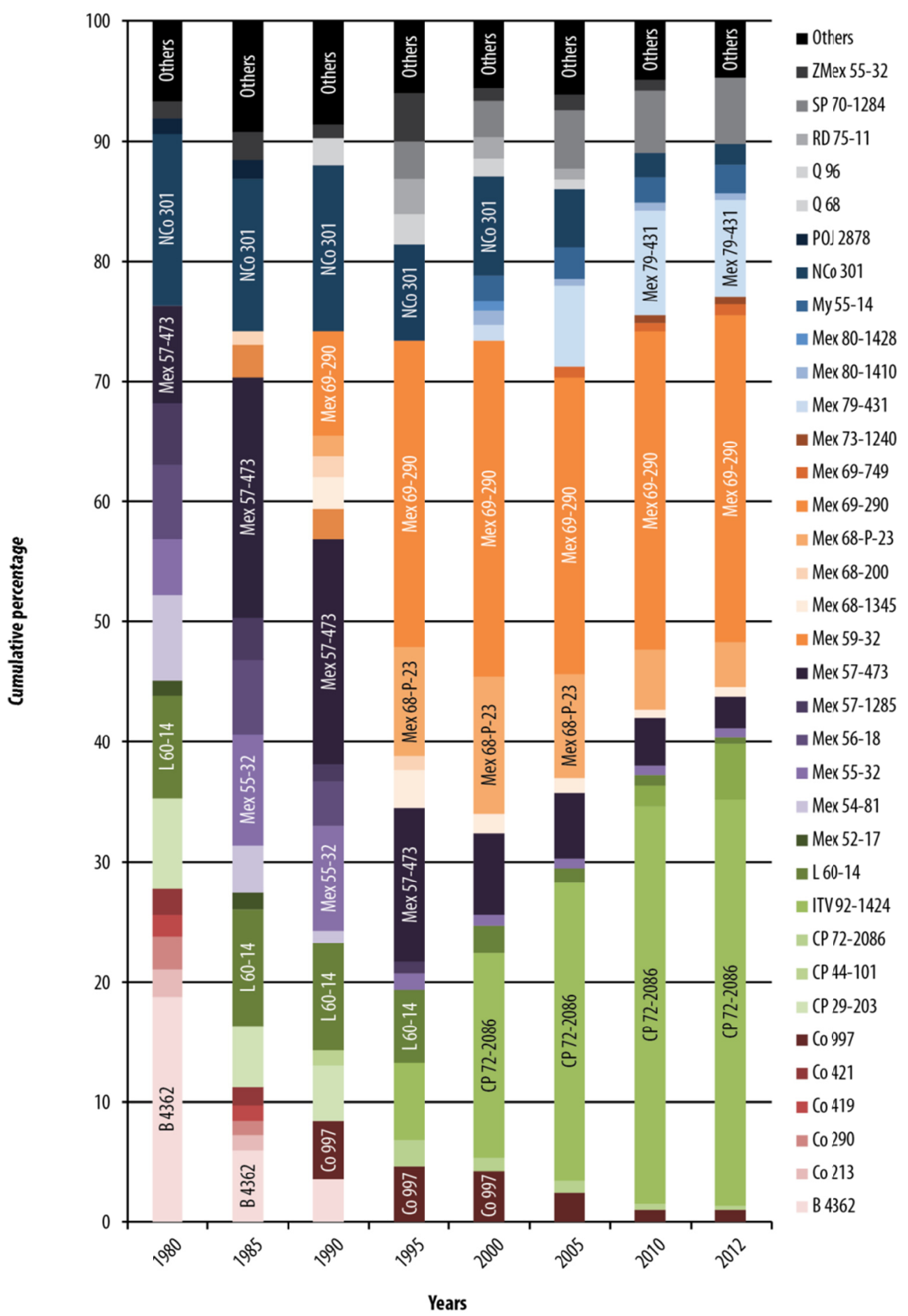

Figure 7. Percentage distribution of foreign and domestic sugarcane varieties in Mexico from 1980 to 2012 (Sources: CNIAA, 2013; MAM, 2013)

In terms of scientific capacity, Mexico has a significant infrastructure, research laboratories and centers of investigation with a scientific base of over 5000 researchers, and the enrollment of students in agricultural sciences in the country amounts to more than 44000 (CONACyT, 2012; ANUIES, 2012; OECD, 2013), which is one of the greatest advantages in meeting the needs of innovation for genetic improvement and in other field and factory processes within this value-chain. 


\section{New Guidelines in the Sugarcane Value-Chain}

Based on the Porter's diamond model (Porter, 2008), Aguilar-Rivera et al. (2013) described the constraints on factor conditions including the high rainfed sugarcane producing areas (more than $60 \%$ of the total), migration and low-qualified labor market, an extraordinarily low $\mathrm{R}+\mathrm{D}+\mathrm{I}$ investment percentage compared with other countries, pre-harvest burning and air pollution, stagnating low sugarcane and sucrose yields, high production costs, byproduct production is not included in the final value of the industry as a whole, and the value-chain is concentrated only on three main products: sucrose, molasses and bagasse. Demand conditions limiting elements encompass a primary domestic market of sugar $(75 \%$ of the sugar produced inland is consumed domestically), byproducts are not industrialized, a dramatic reduction of ethanol production (78.4\%), while HFCS imports are significantly increasing. Concerning related and supporting industries, fewer refineries have certified processes, sugar production relies upon a few varieties, byproducts are not efficiently commercialized, ethanol and energy cogeneration are limited, and networks for $\mathrm{R}+\mathrm{D}+\mathrm{I}$ are lacking. As for the strategy, structure and rivalry, the private sector operates $76 \%$ of the refineries and the remaining $24 \%$ is operated by the government via the Fund of Expropriated Companies from the Sugar Sector (Fideicomiso para la Expropiación de Empresas del sector Azucarero, FEESA), the market is more focused on the offer instead of demand, product differentiation is scarce, and there is a general weakness of the system because of the lack of international competitiveness (the economic health of the system depends on domestic consumption and prices). The government controls the system by regulating prices of raw material and sugar, but has not created a good environment to make the sector competitive and an efficient infrastructure is lacking. Furthermore, the international crisis has not served as a catalyzer for the industry, whereas the country has no diversification programs and new niche markets are not well-designed.

One of the first guidelines for improving the competitiveness of the sugarcane value-chain is to increase human capacity through the development of knowledge and skills for all actors involved, but mainly for primary producers and field technicians. The latter should be continual and consolidate the management training program for information and communication technologies (ICT) for which SAGARPA began in 2008, but has not continued.

While Mexico has the capacity to increase up to seven times the area for sugarcane harvesting (from the current 800000 to 5 million ha), this growth must be accompanied by good planning for the raw material (food, bioenergy, chemical industry), because refineries have not been modernized and the number of distilleries for ethanol has decreased significantly. The greatest potential for such growth is in the states of Chiapas, Jalisco, Morelos and Puebla, while refineries in the states of Campeche, Tabasco and San Luis Potosí would have to redesign their operations due to their lower productivity associated with agronomic-technical, environmental and socioeconomic limitations.

Analyses of the last production cycles (2000 to date) show that field performance has been irregular and, with the exception of the last harvest (2012/2013), the indicator has been declining. Points to address in this respect are associated with the limiting factors already described for the field, but also the possibility of increasing industry competitiveness using different strategies that involve increased performance in the field and refineries for access to credit and surface irrigation. Providing basic products, co-products, byproducts and derivatives for industries as varied as food, health, agriculture, chemistry, energy, transportation, housing and construction, are alternatives that have yet to be analyzed by decision-makers, producers, industries, scientists and academics, in order to take advantage of opportunities involving economic liberalization and industrial growth of the country.

Because internal situations cause lags in the field and refineries and low investment in $R+D+I$, it is necessary to rethink policies and strategies to improve the current system and successfully develop skills and potentials. Generation of domestic technologies, sustainable development of production processes and social responsibility, implementation of communication and information technologies, nanoscience and biotechnology and studies of domestic and global markets, are some of the suggested guidelines for achieving these tasks. Currently, Mexico has the capacity to develop projects for genome and metagenome sequencing, which opens up great possibilities for promoting development of this value-chain.

Thus, the new sugarcane production system in Mexico should be approached using holistic, inter- and transdisciplinary methods. The development of teams with complementary skills and knowledge (producers, industry, policy-makers, scientists and academics from different disciplines) will be critical for the success of these strategies. In work schedules, it will be necessary to develop educational programs, increase human development and knowledge management in the first hierarchical level, primarily for the less-educated producers so that it acts as a trigger for change in the management process. From there, and in accordance with PRONAR, it will be necessary to continue with technical aspects such as the diagnoses of soil conditions and limiting climatic factors; 
tillage and conservation of soil and water; dates and densities of planting; generation and selection of varieties and the production of adequate seed; proper management of crop nutrition (fertilization); integrated management of diseases, pests and weeds; as well as mechanized and green harvesting. A similar work schedule could be applied in the refineries, so that process management innovations are completed, including technological, organizational and commercial forms.

\section{Conclusions}

Sugarcane is a crop with great potential for growth in Mexico because of its potential to achieve more than $800 \mathrm{t}$ $\mathrm{ha}^{-1}$ of fresh matter, compared to a current average value of $70 \mathrm{tha}^{-1}$. Projections for land use predict that sugarcane cultivation in the country could expand to 5 million hectares.

Mexico has important scientific infrastructure, but it is not sufficient to meet the demands of many branches of the industry, so it will be necessary to increase public and private investments which are currently scarce and irregular. Among the priority issues to address is capacity-building for all actors involved in the value-chain, but primarily for producers with lower educational levels, and to continue to work on strengthening programs that generate new varieties (broadening the genetic base) capable of producing even under adverse conditions from climate change, improving agronomic practices for water management and crop nutrition (balanced fertilization based on studies of plant needs), expanding the system of recruitment and use of water and irrigation, continuing the search for sustainable strategies for the integrated management of disease-causing pathogens, pests and weeds, increasing mechanized and green harvesting, improving distribution from the supply areas to make more efficient use of transportation and fuel and of advances in information and communication, including, if possible, improvements in process automation. The diversification of the value-chain is an alternative that could increase the profitability of this activity, but it must be implemented using efficient planning and negotiation with the actors involved. To increase yields in fields and refineries, increased access to credit and irrigation infrastructure are critical. Concerning factor conditions, generation of new varieties, increases in productivity (both in cane and sucrose), diminishing production costs, sustainable and efficient use of water, green harvest, recycle of agricultural residues, digitizing sugarcane fields to improve agricultural precision, and converting conventional sugarcane mills into biorefineries to produce many value-added products such as glycerol, bioethanol, inositol, carbon dioxide, and succinic acid, would be among the actions to be implemented in order to improve the national sugarcane value-chain competitiveness. As for demand conditions, self-sufficiency for both sucrose and ethanol, diversification of white and brown sugars, using bagasse to fuel and cogenerate steam and electricity, carbon sequestration and carbon credits for clean development mechanisms, animal feed and supplements, high-value niche markets with a variety of novel products, and organic soil amendments need also to be approached. Furthermore, inputs, machinery, technology and services, energy and other sales of byproducts, inter-industry cooperation at national and international scales, as well as logistic operations must be taken into consideration in relation to similar and supporting industries. Finally, regarding firm strategy, structure and rivalry, the Mexican sugarcane production system must consider human resources to further education and technical training, technical assistance, process certification, wastewater treatment, integration and company management, farmer organization and prospective analyses, which are the primary actions to be carried out in order to reach competitiveness expectations. As well, by recognizing the importance of development of adequate infrastructure for sustaining growth and to ensure inclusiveness of the growth process, the government will continue to play a lead role in infrastructure development, as well as in legislation, establishment of new biorefineries, free trade agreements, competitive environments, $\mathrm{R}+\mathrm{D}+\mathrm{I}$, regional clusters and access to information. Last, the Mexican sugarcane agro-industrial system has opportunities related to geographical location, emergence of new markets, bioenergy needs and a growing trend of cooperative relationships between private companies and universities.

The sugarcane value-chain is the second largest in the country, and is strategic in the generation of jobs, alternative energy, and substrates for other industries such as pharmaceutical, sucrochemistry and new approaches such as novel bio-factories. In order to make the Mexican sugarcane system a globally competitive one, the current crisis in this value-chain demands considerable effort from all stakeholders, including education and human development, while considering current and future technological advances.

\section{Acknowledgments}

The authors are very much grateful to the Priority Research Line 5 "Microbial, plant and animal biotechnology" from the Colegio de Postgraduados for facilities and financial support, and to the Mexican National Council for Science and Technology (CONACYT) for the fellowship given to HESH. 


\section{References}

Aday, D. O. C., Barroso, M. F., \& Izquierdo, R. L. N. (2003). Estimación de pérdidas causadas por Diatrea saccharalis (Fab.) en la provincia de Villa Clara, Cuba. Centro Agrícola, 30, 37-40.

AGROASEMEX. (2006). La experiencia mexicana en el desarrollo y operación de seguros paramétricos orientados la la agricultura. from http://www.agroasemex.gob.mx/index.php/es/atencionclientes/descargas/func-startdown/292/

AGROASEMEX. (2013). Programa del subsidio a la prima del seguro agropecuario. Informe de avance al tercer trimestre de 2013. Retrieved from http://www.agroasemex.gob.mx/images/RecursosFederales/SubsidioPrima/PROGRAMA_DEL_SUBSIDI O_A_LA_PRIMA_DEL_SEGURO_AGROPECUARIO_3ER_TRIMESTRE_2013.pdf

Aguilar-Rivera, N. (2012). Paradigma de la diversificación de la agroindustria azucarera de México. Convergencia Revista de Ciencias Sociales, 59, 187-213.

Aguilar-Rivera, N. (2013). Análisis de productividad de etanol de caña de azúcar en ingenios azucareros de México. Ciencia Ergo Sum, 20, 17-28.

Aguilar-Rivera, N., Espinosa-López, L. A., Herrera S., A., Castillo M., A., \& Rodríguez L., D. A. (2013). Diamante de competitividad de la agroindustria azucarera en México. Revista ATAM, 26, 28-38.

Aguilar-Rivera, N., Galindo-Mendoza, G., Fortanelli-Martínez, J., \& Contreras-Servín, C. (2011). Factores de competitividad de la agroindustria de la caña de azúcar en México. Región y Sociedad, 13, 261-297.

Aguilar-Rivera, N., Rodríguez, L. D. A., Enríquez, R. V., Castillo, M. A., \& Herrera, S. A. (2012). The Mexican sugarcane industry: overview, constraints, current status and long-term trends. Sugar Technology, 14, 207-222. http://dx.doi.org/10.1007/s12355-012-0151-3

Aguilar-Rivera, N., Rodríguez-Lagunes, D. A., \& Castillo-Morán, A. (2010). Sugar, coproducts and byproducts on sugarcane agribusiness diversification. VirtualPro, 106, 1-28.

Alejandre-Rosas, J. A., Galindo-Tovar, M. E., \& Lee-Espinoza, H. E. (2010). Variabilidad genética en 22 variedades hibridas de caña de azúcar (Saccharum spp. Híbrido). Phyton, 79, 87-94.

ANUIES [Asociación Nacional de Universidades e Instituciones de Educación Superior]. (2012). Anuario estadístico digital 2012. Asociación de universidades e instituciones de educación superior. México, D. F. Retrieved from http://www.anuies.mx/content.php?varSectionID=166

Arredondo-Bernal, H. C., \& Rodríguez del Bosque, L. A. (2008). Casos de Control Biológico en México. MundiPrensa-INIFAP. México, D. F.

Blackaller, A. C. (2011). La agroindustria mexicana de la caña de azúcar en México. Unión Nacional de Cañeros, A.C.-C.N.P.R.

from http://www.caneros.org.mx/site_caneros/descargas/pleno_aguascalientes/presentacion_Blackaller.pdf

Blackaller, A. C. (2013). Aprueba gobierno federal mil 500 millones de pesos para paquete tecnológico de la caña de azúcar: CBA. Retrieved from http://www.caneros.org.mx/site_caneros/bol/bol01/BOLETIN_OCT_021.pdf

Cervantes, F. A., \& Ballesteros-Barrera, C. (2012). Estudios sobre la biología de roedores silvestres mexicanos. Instituto Biología-UNAM \& Universidad Autónoma Metropolitana. Retrieved from $\mathrm{http}: / /$ www.mastozoologiamexicana.org/books/Estudio_sobre_biologia_roedores_mexicanos.pdf

Chinea-Martín, A., \& Milanés-Ramos, N. (2006). Enfermedades de la caña de azúcar en México. In A. Castillo-Morán, A. Rodríguez-Lagunes, N. Milanés-Ramos, N. Aguilar-Rivera, P. Ordoñez-Barahona, V. Enríquez-Ruvalcaba, A. Herrera-Solano, \& H. Ortiz-Romero (Eds.), Temas Selectos de la Caña de Azúcar 1 (pp.72-85). Dirección General Editorial. Universidad Veracruzana, Veracruz, México.

CIDCA [Centro de Investigación y Desarrollo de la Caña de Azúcar]. (2013). Centro de Investigación y Desarrollo de la Caña de Azúcar (CIDCA). Retrieved from http://www.camaraazucarera.org.mx/cidca.asp

CNIAA [Centro de Investigación y Desarrollo de la Caña de Azúcar]. (2013). Resumen de producción de la agroindustria azucarera mexicana zafras 1959/1960-2012/2013. Cámara Nacional de las Industrias Alcoholera y Azucarera. México, D. F.

CNPR [Confederación Nacional de Productores Rurales]. (2004). Mosca pinta. Retrieved from http://www.caneros.org.mx/site_caneros/investigaciones/moscapinta2004.pps 
CNPR [Confederación Nacional de Productores Rurales]. (2013). Estadísticas de la agroindustria de la caña de azúcar 2003 - 2012. Confederación Nacional de Productores Rurales. Unión Nacional de Cañeros. Retrieved from http://www.caneros.org.mx/site_caneros/estadisticas/nacional.pdf

COLPOS [Colegio de Postgraduados]. (2008). Manejo sustentable de la fertilidad del suelo y de la nutrición de la caña de azúcar. Colegio de Postgraduados. Retrieved from http://siazucar.siap.gob.mx/materiales/pdf/Resumen_Informe.pdf

CONABIO [Comisión Nacional para el Conocimiento y Uso de la Biodiversidad]. (2012). Malezas de México. Comisión Nacional para el Conocimiento y Uso de la Biodiversidad. México, D. F. Retrieved from http://www.conabio.gob.mx/malezasdemexico/2inicio/home-malezas-mexico.htm.

CONACyT [Consejo Nacional de Ciencia y Tecnología] (2012). Informe general del estado de la ciencia, la tecnología y la innovación. Consejo Nacional de Ciencia y Tecnología. México, D. F. Retrieved from http://www.siicyt.gob.mx/siicyt/docs/Estadisticas3/Informe2011/INFORME_2011.pdf

CONADESUCA [Comité Nacional para el Desarrollo Sustentable de la Caña de Azúcar]. (2011a). Estrategia integral para incrementar la productividad del campo cañero. Retrieved from http://www.cndsca.gob.mx/foro\%20Jalisco/Estrategia\%20integral.pdf

CONADESUCA [Comité Nacional para el Desarrollo Sustentable de la Caña de Azúcar]. (2011b). Proyecto nacional para el control de plagas y enfermedades de la caña de azúcar. Retrieved from http://www.colpos.mx/web11/pdf/Investigacion/Reunion/3CP\%20septiembre\%202012.pdf

CONADESUCA [Comité Nacional para el Desarrollo Sustentable de la Caña de Azúcar]. (2013). Sistema INFOCaña. Campo y Fábrica: Zafra 2012-2013. Retrieved from http://www.campomexicano.gob.mx/azcf/entrada/menu.php

CONAPO [Consejo Nacional de Población]. (2010a). Índice de marginación por entidad y municipio 2010. Retrieved

from http://www.conapo.gob.mx/es/CONAPO/Indices_de_Marginacion_2010_por_entidad_federativa_y_munici pio

CONAPO [Consejo Nacional de Población]. (2010b). Índice de marginación por localidad 2010. Retrieved from http://www.conapo.gob.mx/es/CONAPO/Indice_de_marginacion_por_localidad_2010

Cruz, G. E. (2009). El manual del productor de caña de azúcar. ATIDER, México, D. F.

Dal-Bianco, M., Sampaio-Carneiro, M., Takeshi-Hotta, C., Giacomini-Chapola, L., Hoffmann, H. P., Franco-Garcia, A. A., \& Mendes-Souza, G. (2012). Sugarcane improvement: how far can we go? Current Opinion in Biotechnology, 23, 265-270. http://dx.doi.org/10.1016/j.copbio.2011.09.002

Esqueda, V. A. (1999). Control de malezas en caña de azúcar con clomazone y ametrina. Agronomía Mesoamericana, 10, 23-30.

FAOSTAT. (2013). Food and agricultural commodities production. Retrieved from http://faostat.fao.org/DesktopDefault.aspx?PageID=339\&lang=en

Flores, C. S. (2001). Las variedades de caña de azúcar en México. Editorial ATAM, México, D. F.

Flores, C. S. (2007). Las plagas de la caña de azúcar en México. Editorial ATAM, México, D. F.

Flores, R. C. (2012). Proyectos caña de azúcar: Avances y resultados 2012. Retrieved from http://www.caneros.org.mx/site_caneros/descargas/pleno_gdl/04_PONENCIA_ESTACIONES_HIBRIDA CION.pdf

Gómez-Merino, F. C., \& Hernández-Anguiano, A. M. (2013). El contexto del sector agroalimentario en México. In A. M. Hernández-A., F. C. Gómez, M., L. M. Pérez H., \& J. A. Villanueva J. (Eds.), Líneas prioritarias de investigación. Informe de gestión 2009-2011. Colegio de Postgraduados, Montecillo, México (pp. 11-20).

Gómez-Merino, F. C., Trejo-Téllez, L. I., \& Sentíes-Herrera, H. E. (2014). Sugarcane as a novel biofactory: potentialities and challenges. In R. Guevara-González, I. Torres-Pacheco (Eds.), Biosystems engineering: Biofactories for food production in Century XXI (pp. 129-149). Cham, Switzerland: Springer. http://dx.doi.org/10.1007/978-3-319-03880-3_5

González-Jiménez, V., Valdez-Balero, A., Gómez-Merino, F. C., Silva-Rojas, H. V., Pérez-Flores, J., \& Ortiz-García, C. F. (2011). Molecular characterization of sugarcane varieties cultivated in Tabasco state, Mexico. Biotecnología Vegetal, 11, 107-113. 
Goran, M. I., Ulijaszek S. J., \& Ventura E. E. (2013). High fructose corn syrup and diabetes prevalence: a global perspective. Global Public Health, 8, 55-64. http://dx.doi.org/10.1080/17441692.2012.736257

Hernández-Velázquez, V. M., Lina-García, L. P., Obregón-Barboza, V., Trejo-Loyo, A. G., \& Peña-Chora, G. (2012). Pathogens associated with sugarcane borers, Diatraea spp. (Lepidoptera: Crambidae): a review. International Journal of Zoology, 2012. http://dx.doi.org/10.1155/2012/303589

IMPA [Instituto para el Mejoramiento de la Producción Azucarera]. (1983). Programa de variedades. Objetivos, importancia y metodología experimental. Instituto para el Mejoramiento de la Producción Azucarera-Cámara Nacional de la Industria Azucarera y Alcoholera, México, D. F.

INEGI [Instituto Nacional de Estadística y Geografía]. (2012). Censos agropecuarios. Atlas agropecuario de México. Retrieved from http://www.inegi.org.mx/est/contenidos/Proyectos/Agro/default.aspx

LDSCA [Ley de Desarrollo Sustentable de la Caña de Azúcar]. (2005). Ley de Desarrollo Sustentable de la Caña de Azúcar. Diario Oficial de la Federación. Retrieved from http://www.ordenjuridico.gob.mx/leyes.php

MAM [Manual Azucarero Mexicano]. (2013). Manual azucarero Mexicano Edición 2013. Grupos industriales y producción 2011/2012. Compañía Editora del Manual Azucarero. México, D. F.

Márquez, J. M. (2002). Metodología del muestreo de daño y pérdidas ocasionadas por rata en caña de azúcar. Retrieved from http://www.cengicana.org/publicaciones/manejo-rata/Perdidas_por_Rodedores_y_ Metodologia_de-Muestreo.31.pdf

Méndez, C., V., Elorza, M., P., Maruri, G., J. M., Elorza, M., O., \& Martínez, S, C. E. (2013). Plan de exportación de piloncillo de la zona norte de Veracruz hacia los mercados de California y Texas. Revista Cientifica Biológico Agropecuaria Tuxpan, 1, 27-38.

Moyer, M. (2010). How much is left? A graphical accounting of the limits to what one planet can provide. Scientific American - Environment, September, 2010, 74-81.

OECD [Organization for Economic Cooperation and Development]. (2013). OECD science, technology and industry scoreboard 2013. Innovation for growth. Paris, France. http://dx.doi.org/10.1787/sti_scoreboard2013-en

Palma-López, D. J. (2009). La caña de azúcar y el clima. In A. Valdez B., A. Guerrero P., E. García L., \& J. J. Obrador O. (Eds.), Manual para el cultivo y producción de caña de azúcar (pp. 8-15). Colegio de Postgraduados, México.

Pérez-Zamorano, A. (2007). Tenencia de la tierra y agroindustria azucarera. Editorial Porrua. México, D. F.

Porter, M. E. (2008). The five competitive forces that shape stategy. Harvard Business Review, 86, 58-77. Retrieved from http://hbr.org/2008/01/the-five-competitive-forces-that-shape-strategy/ar/1

PRONAC [Programa Nacional de la Agroindustria de la Caña de Azúcar]. (2007). Programa Nacional de la Agroindustria de la Caña de Azúcar (PRONAC) 2007-2012. Cámara Nacional de las Industrias Azucarera y Alcoholera. Retrieved from http:/www.camaraazucarera.org.mx/pagina_2011/Pronac/Default.asp

PRONAR [Programa Nacional de Alta Resntabilidad del Campos Cañero]. (2009). Proyecto Nacional de Alta Rentabilidad para el Reordenamiento y Transformación del Campo Cañero Mexicano. Retrieved from http://www.zafranet.com/---files/PDF/PRONARHomologada.pdf

Quintero-Núñez, S. (2012). Proyecto de mejoramiento genético de caña de azúcar (PMGCA). Grupo PIASA. Retrieved from http://www.cndsca.gob.mx/citcana/PROYECTO\%20MEJORAMIENTO\%20GEN\%C3\% 89TICO\%20PIASA.pdf

Rebollar-Alviter, A., Sánchez-Pale, J. R., \& Silva-Rojas, H. V. (2012). Manejo integrado de Fusarium spp. en variedades cultivadas y prometedoras de caña de azúcar. CANIEM. México, D. F.

Rivera, C. (2012). Transferencia de riego en la agroindustria de caña de azúcar. Retrieved from http://www.caneros.org.mx/site_caneros/descargas/pleno_gdl/02_Rolando_Rivera_AgroCorporateSolutions _Presentation_CANA_RR2.pdf

SAGARPA [Secretaría de Agricultura, Ganadería, Desarrollo Rural, Pesca y Alimentación]. (2009). Sistema Nacional de Información de la Agroindustria Azucarera. Secretaría de Agricultura, Ganadería, Desarrollo Rural, Pesca y Alimentación. Aguascalientes, México. Retrieved from http://mapserver.inegi.org.mx/geografia/espanol/eventos/cng2009/memoria/cng2009/20091019\%20siazucar $\% 20$ para $\% 20 \mathrm{cng} \% 20$ julio\%20c-rivera.pps 
Salgado-García, S., Lagunes-Espinoza, L. C., Núñez-Escobar, R., Ortiz-García, C. F., Bucio-Alanis, L., \& Aranda-Ibañez, E. (2013). Caña de azúcar. Producción sustentable. MundiPrensa-Colegio de Postgraduados. México, D. F.

Sánchez, G. C. (2005). Manejo integrado de plagas de la caña de azúcar (Mosca pinta y Barrenadores). Retrieved from http://biblioteca.inifap.gob.mx:8080/xmlui/bitstream/handle/123456789/321/66.pdf?sequence=1

Secretaría de Economía. (2012). Análisis de la situación económica, tecnológica y de política comercial del sector edulcorantes en México. Retrieved from http://www.economia.gob.mx/files/comunidad_negocios/industria_comercio/Analisis_Sectorial_Mercado_ Edulcorantes.pdf

SENASICA [Servicio Nacional de Sanidad, Inocuidad y Calidad Agroalimentaria]. (2011). Listado de plaguicidas de uso agrícola. Última actualización enero 2011. Retrieved from http://www.senasica.gob.mx/

SIAP [Servicio de Información Agroailmentaria y Pesquera]. (2012). Cierre de la producción agrícola por cultivo 2012. Retrieved from http://www.siap.gob.mx/index.php?option=com_wrapper\&view=wrapper\&Itemid=350

SIAP [Servicio de Información Agroailmentaria y Pesquera]. (2013). Una mirada al panorama agroalimentario de México y el mundo. Retrieved from http://www.campomexicano.gob.mx/boletinsiap/007-e.html

Singelmann, P. (2003). La transformación política de México y los gremios cañeros del PRI. Revista Mexicana de Sociología, 65, 117-152. http://dx.doi.org/10.2307/3541517

SNITT [Sistema Nacional de Investigación y Transferencia de Tecnología para el Desarrollo Rural]. (2013). Proyectos en proceso y concluidos. Sistema Nacional de Investigación y Transferencia Tecnológica para el Desarrollo Rural Sustentable. Retrieved from http://www.snitt.org.mx/p_cientifica.html

Sosa-Rubí, S. G., Galárraga O., \& López-Ridaura R. (2009). Diabetes treatment and control: the effect of public health insurance for the poor in Mexico. Bulletin of the World Health Organization, 87, 485-564.

Toriello, C., Montoya-Sansón, E., Zavala-Ramírez, M., Navarro-Barranco, H., Basilio-Hernández, D., Hernández-Velázquez, V. \& Mier, T. (2008). Virulence and thermotolerance of monospore cultures of Metarhizium anisopliae var. anisopliae isolated from spittlebugs (Hemiptera: Cercopidae). Revista Mexicana de Micología, 28, 57-66.

USDA. (2014). Sugar and sweeteners yearbook tables. United States Department of Agriculture. Economic Reseach Service. Retrieved from http://www.ers.usda.gov/data-products/sugar-and-sweeteners-yearbook-tables.aspx $\# 25522$

Vásquez-López, I., Lorenzo-Monterrubio, C., \& Bolaños-Citalan, J. (2013). Roedores habitantes de los agroecosistemas cañeros. Guía de campo. PROSGRAF, Xalapa, Veracruz, México.

Waclawovsky, A. J., Sato, P. M., Lembke, C. G., Moore, P. H., \& Souza, G. M. (2010). Sugarcane for bioenergy production: an assessment of yield and regulation of sucrose content. Plant Biotechnology Journal, 8, 263-276. http://dx.doi.org/10.1111/j.1467-7652.2009.00491.x

Yadav, D. V., Jain, R., \& Rai, R. K. (2010). Impact of heavy metals on sugarcane. In I. Sherameti, A. Varma (Eds.), Soil Heavy Metals-Soil Biology, 19 (pp. 339-367). Heidelberg, Germany: Springer. Retrieved from http://link.springer.com/book/10.1007\%2F978-3-642-02436-8

ZAFRANET. (2013). Avances en la producción de azúcar (Zafra). Nuestro país, sexto productor mundial de azúcar $y$ quinto en exportaciones del dulce. Retrieved from http://www.zafranet.com/category/es/analisis-es/mexico-analisis-es/avances-de-la-zafra/ 


\section{APPENDIX A Supplementary Material}

Table S1. Physical and chemical soil indicators and the percentage coverage in the areas supplying sugar refineries in Mexico

\begin{tabular}{|c|c|c|c|c|c|c|c|c|c|c|c|}
\hline $\mathrm{EC}$ & & $\mathrm{pH}$ & & $\mathrm{OM}$ & & IA & & Clay & & WR & \\
\hline $\mathrm{dS} \mathrm{m}^{-1}$ & $\% *$ & Value & $\% *$ & Content & $\% *$ & $\mathrm{cmol} \mathrm{kg}^{-1}$ & $\% *$ & Percent content & $\% *$ & Percent & $\% *$ \\
\hline$<1.0$ & 91.3 & $<4.5$ & 6.5 & $<1.0$ & 5.5 & 0.0 & 65.1 & $<10$ & 2.2 & 1 & 77.8 \\
\hline $1.0-2.0$ & 5.9 & $4.6-5.5$ & 16.6 & $1.0-2.0$ & 17.7 & $0.01-0.10$ & 11.6 & $10-20$ & 12.2 & 2 & 4.0 \\
\hline $2.1-3.0$ & 2.7 & $5.6-6.5$ & 21.9 & $2.1-3.0$ & 27.0 & $0.11-0.20$ & 6.2 & $21-30$ & 18.7 & 3 & 7.2 \\
\hline $3.1-5.0$ & 7.1 & $6.6-7.5$ & 18.6 & $3.1-5.0$ & 37.2 & $0.21-0.40$ & 4.4 & $31-40$ & 20.8 & 4 & 6.2 \\
\hline$>5.1$ & 0.1 & $>7.6$ & 36.4 & $>5.1$ & 12.6 & $>0.41$ & 12.6 & $>41$ & 46.0 & 5 & 4.9 \\
\hline
\end{tabular}

Source: COLPOS (2008). EC: Electrical conductivity; OM: Organic material; IA: Interchangeable acidity; WR: Waterlogging risk.

* Percentage values are for the surface area having the given characteristic with regard to the total area devoted to sugarcane production in Mexico.

Table S2. N, P, K, Ca and Mg concentrations in soils from lands supplying sugar refineries in Mexico

\begin{tabular}{llllllllll}
\hline \multicolumn{2}{l}{ Nitrogen } & \multicolumn{3}{l}{ Phosphorous } & \multicolumn{2}{l}{ Potassium } & \multicolumn{2}{l}{ Calcium } & \multicolumn{3}{l}{ Magnesium } \\
\hline $\mathrm{kg} \mathrm{ha}^{-1}$ & $\%^{*}$ & $\mathrm{~kg} \mathrm{ha}^{-1}$ & $\%^{*}$ & $\mathrm{~kg} \mathrm{ha}^{-1}$ & $\%^{*}$ & $\mathrm{~kg} \mathrm{ha}^{-1}$ & $\%^{*}$ & $\mathrm{~kg} \mathrm{ha}^{-1}$ & $\%^{*}$ \\
\hline$<10$ & 6.7 & $<5$ & 29.4 & $<40$ & 0.2 & $<250$ & 0.2 & $<50$ & 0.1 \\
$10-20$ & 68.5 & $5-10$ & 16.2 & $40-80$ & 6.2 & $250-2500$ & 22.1 & $50-100$ & 1.1 \\
$21-30$ & 14.7 & $11-15$ & 9.9 & $81-120$ & 12.3 & $2501-5000$ & 34.7 & $101-500$ & 33.5 \\
$31-50$ & 7.4 & $16-30$ & 17.3 & $212-160$ & 7.4 & $5001-10000$ & 33.6 & $501-1000$ & 26.6 \\
$>50$ & 2.7 & $>30$ & 27.2 & $>160$ & 74.0 & $>10000$ & 9.4 & $>1000$ & 38.7 \\
\hline
\end{tabular}

Source: COLPOS (2008).

* Percentage values indicate the surface area having the given characteristic with regard to the total area devoted to sugarcane production in Mexico.

Table S3. Concentrations of $\mathrm{Fe}, \mathrm{Cu}, \mathrm{Zn}$ and $\mathrm{Mn}$ from supply area soils for sugar refineries in Mexico

\begin{tabular}{llllllll}
\hline Iron & \multicolumn{3}{l}{ Copper } & \multicolumn{2}{l}{ Zinc } & \multicolumn{3}{c}{ Manganese } \\
\hline $\mathrm{mg} \mathrm{kg}^{-1}$ & $\%^{*}$ & $\mathrm{mg} \mathrm{kg}^{-1}$ & $\%^{*}$ & $\mathrm{mg} \mathrm{kg}^{-1}$ & $\%^{*}$ & $\mathrm{mg} \mathrm{kg}^{-1}$ & $\%^{*}$ \\
\hline$<0.5$ & 1.0 & $<0.5$ & 40.7 & $<0.5$ & 54.7 & $<0.5$ & 1.8 \\
$0.5-1.0$ & 0.2 & $0.5-1.0$ & 7.6 & $0.5-1.0$ & 12.1 & $0.5-1.0$ & 0.2 \\
$1.1-3.0$ & 0.6 & $1.1-3.0$ & 31.4 & $1.1-3.0$ & 18.7 & $1.1-3.0$ & 1.9 \\
$3.1-5.0$ & 1.0 & $3.1-5.0$ & 9.6 & $3.1-5.0$ & 7.2 & $3.1-5.0$ & 1.3 \\
$>5.0$ & 97.2 & $>5.0$ & 10.8 & $>5.0$ & 7.3 & $>5.0$ & 94.8 \\
\hline
\end{tabular}

Source: COLPOS (2008).

* Percentage values are for the surface area having the given characteristic with regard to the total area devoted to sugarcane production in Mexico. 
Table S4. Primary climate and soil characteristics of the six sugarcane production regions in Mexico

\begin{tabular}{|c|c|c|c|c|}
\hline Region & State & Predominant Climate & $\begin{array}{l}\text { Mean Annual Temperature } \\
\text { and Precipitation }\end{array}$ & Predominant Soils \\
\hline Northwest & Sinaloa & $\begin{array}{l}\text { Hot sub-humid: } 48 \% \\
\text { Dry and semi-arid: } 40 \% \\
\text { Very arid: } 10 \% \\
\text { Temperate sub-humid: } \\
2 \%\end{array}$ & $\begin{array}{l}\text { Mean: } 25^{\circ} \mathrm{C} \\
\text { Maximum: } 36{ }^{\circ} \mathrm{C} \\
\text { Minimum: } 10.5^{\circ} \mathrm{C} \\
\text { Precipitation: } 790 \mathrm{~mm}\end{array}$ & $\begin{array}{l}\text { Cambisol } \\
\text { Calcic kastanozem } \\
\text { Phaeozem } \\
\text { Regosol } \\
\text { Vertisol }\end{array}$ \\
\hline \multirow{4}{*}{ Pacific } & Nayarit & $\begin{array}{l}\text { Hot sub-humid: } 91.5 \% \\
\text { Temperate sub-humid: } \\
6 \% \\
\text { Dry and semi-arid: } 2 \% \\
\text { Hot humid: } 0.5\end{array}$ & $\begin{array}{l}\text { Mean: } 25^{\circ} \mathrm{C} \\
\text { Maximum: } 35^{\circ} \mathrm{C} \\
\text { Minimum: } 12^{\circ} \mathrm{C} \\
\text { Precipitation: } 1100 \mathrm{~mm}\end{array}$ & $\begin{array}{l}\text { Humic acrisol } \\
\text { Hortic acrisol } \\
\text { Humic andosol } \\
\text { Dystric cambisol } \\
\text { Eutric cambisol } \\
\text { Humic cambisol } \\
\text { Haplic phaeozem } \\
\text { Vertic gleysol } \\
\text { Chromic luvisol } \\
\text { Hortic luvisol } \\
\text { Eutric regosol }\end{array}$ \\
\hline & Colima & $\begin{array}{l}\text { Hot sub-humid: } 86 \% \\
\text { Arid and semi-arid: } \\
12.5 \% \\
\text { Temperate sub-humid: } \\
1.5 \%\end{array}$ & $\begin{array}{l}\text { Mean: } 25^{\circ} \mathrm{C} \\
\text { Maximum: } 30^{\circ} \mathrm{C} \\
\text { Minimum: } 18^{\circ} \mathrm{C} \\
\text { Precipitation: } 900 \mathrm{~mm}\end{array}$ & $\begin{array}{l}\text { Humic andosol } \\
\text { Eutric cambisol } \\
\text { Ferric cambisol } \\
\text { Haplic phaeozem } \\
\text { Lithosol } \\
\text { Haplic luvisol } \\
\text { Chromic regosol } \\
\text { Eutric regosol } \\
\text { Pellic vertisol }\end{array}$ \\
\hline & \multirow[t]{2}{*}{ Jalisco } & $\begin{array}{l}\text { Hot sub-humid: } 68 \% \\
\text { Temperate sub-humid: } \\
18 \% \\
\text { Arid and semi-arid: } 14 \%\end{array}$ & $\begin{array}{l}\text { Mean: } 20.5^{\circ} \mathrm{C} \\
\text { Maximum: } 23^{\circ} \mathrm{C} \\
\text { Minimum: } 7{ }^{\circ} \mathrm{C} \\
\text { Precipitation: } 1000 \mathrm{~mm}\end{array}$ & $\begin{array}{l}\text { Humic andosol } \\
\text { Chromic cambisol } \\
\text { Ferric cambisol } \\
\text { Eutric cambisol } \\
\text { Calcaric phaeozem } \\
\text { Haplic phaeozem } \\
\text { Fluvisol } \\
\text { Lithosol } \\
\text { Haplic luvisol } \\
\text { Chromic luvisol } \\
\text { Eutric planosol } \\
\text { Luvic planosol } \\
\text { Chromic regosol } \\
\text { Eutric regosol } \\
\text { Calcaric regosol } \\
\text { Dystric regosol } \\
\text { Eutric regosol } \\
\text { Chromic vertisol } \\
\text { Pellic vertisol }\end{array}$ \\
\hline & & Hot sub-humid: $54.5 \%$ & Mean: $20^{\circ} \mathrm{C}$ & Chernozem \\
\hline
\end{tabular}




\begin{tabular}{|c|c|c|c|c|}
\hline & & $\begin{array}{l}\text { Temperate sub-humid: } \\
29 \% \\
\text { Arid and semi-arid: } 15 \% \\
\text { Temperate humid: } 1 \% \\
\text { Hot humid: } 0.5 \%\end{array}$ & $\begin{array}{l}\text { Maximum: } 31^{\circ} \mathrm{C} \\
\text { Minimum: } 8{ }^{\circ} \mathrm{C} \\
\text { Precipitation: } 850 \mathrm{~mm}\end{array}$ & $\begin{array}{l}\text { Kastanosem } \\
\text { Podzol }\end{array}$ \\
\hline \multirow[b]{2}{*}{ Center } & Morelos & $\begin{array}{l}\text { Hot sub-humid: } 87 \% \\
\text { Temperate humid: } 11 \% \\
\text { Temperate sub-humid: } \\
2 \%\end{array}$ & $\begin{array}{l}\text { Mean: } 21.5^{\circ} \mathrm{C} \\
\text { Maximum: } 32{ }^{\circ} \mathrm{C} \\
\text { Minimum: } 10^{\circ} \mathrm{C} \\
\text { Precipitation: } 900 \mathrm{~mm}\end{array}$ & $\begin{array}{l}\text { Fluvisol } \\
\text { Kastanozem } \\
\text { Chernozem } \\
\text { Haplic phaeozem } \\
\text { Lithosol } \\
\text { Vertisol }\end{array}$ \\
\hline & Puebla & $\begin{array}{l}\text { Temperate sub-humid: } \\
35 \% \\
\text { Hot: } 25 \% \\
\text { Arid: } 19 \% \\
\text { Temperate humid: } 7 \% \\
\text { Cold: } 0.2 \%\end{array}$ & $\begin{array}{l}\text { Mean: } 17.5^{\circ} \mathrm{C} \\
\text { Maximum: } 28.5^{\circ} \mathrm{C} \\
\text { Minimum: } 6.5^{\circ} \mathrm{C} \\
\text { Precipitation: } 1270 \mathrm{~mm}\end{array}$ & $\begin{array}{l}\text { Cambisol } \\
\text { Phaeozem } \\
\text { Fluvisol } \\
\text { Lithosol } \\
\text { Luvisol } \\
\text { Regosol } \\
\text { Vertisol } \\
\text { Xerosol }\end{array}$ \\
\hline \multirow[b]{2}{*}{ Northeast } & Tamaulipas & $\begin{array}{l}\text { Hot sub-humid: } 58 \% \\
\text { Arid and semi-arid: } 38 \% \\
\text { Temperate sub-humid: } \\
2 \% \\
\text { Hot humid: } 2 \%\end{array}$ & $\begin{array}{l}\text { Mean: } 22{ }^{\circ} \mathrm{C} \\
\text { Maximum: } 23.5^{\circ} \mathrm{C} \\
\text { Minimum: } 10{ }^{\circ} \mathrm{C} \\
\text { Precipitation: } 780 \mathrm{~mm}\end{array}$ & $\begin{array}{l}\text { Eutric fluvisol } \\
\text { Lithosol } \\
\text { Rendzic } \\
\text { Pellic vertisol }\end{array}$ \\
\hline & $\begin{array}{l}\text { San Luis } \\
\text { Potosí }\end{array}$ & $\begin{array}{l}\text { Arid and semi-arid: } 71 \% \\
\text { Hot sub-humid: } 15 \% \\
\text { Hot humid: } 10 \% \\
\text { Very arid: } 2.5 \% \\
\text { Temperate sub-humid: } \\
1.5 \%\end{array}$ & $\begin{array}{l}\text { Mean: } 21^{\circ} \mathrm{C} \\
\text { Maximum: } 32{ }^{\circ} \mathrm{C} \\
\text { Minimum: } 8.4{ }^{\circ} \mathrm{C} \\
\text { Precipitation: } 950 \mathrm{~mm}\end{array}$ & $\begin{array}{l}\text { Lithosol } \\
\text { Calcaric regosol } \\
\text { Rendzic } \\
\text { Pellic vertisol }\end{array}$ \\
\hline \multirow[t]{2}{*}{ Gulf } & Veracruz & $\begin{array}{l}\text { Hot sub-humid: } 53.5 \% \\
\text { Hot humid: } 41 \% \\
\text { Temperate humid: } 3.5 \% \\
\text { Temperate: } 1.5 \% \\
\text { Arid and semi-arid: } 0.5 \% \\
\text { Very cold: } 0.05 \%\end{array}$ & $\begin{array}{l}\text { Mean: } 23{ }^{\circ} \mathrm{C} \\
\text { Maximum: } 32{ }^{\circ} \mathrm{C} \\
\text { Minimum: } 13{ }^{\circ} \mathrm{C} \\
\text { Precipitation: } 1500 \mathrm{~mm}\end{array}$ & $\begin{array}{l}\text { Acrisol } \\
\text { Fluvisol } \\
\text { Humic andosol } \\
\text { Hortic andosol } \\
\text { Cambisol } \\
\text { Phaeozem } \\
\text { Mollic gleysol } \\
\text { Lithosol } \\
\text { Lixisol } \\
\text { Luvisol } \\
\text { Regosol } \\
\text { Rendzic } \\
\text { Vertisol }\end{array}$ \\
\hline & Tabasco & $\begin{array}{l}\text { Hot humid: } 95.5 \% \\
\text { Hot sub-humid: } 4.5 \%\end{array}$ & $\begin{array}{l}\text { Mean: } 27^{\circ} \mathrm{C} \\
\text { Maximum: } 36{ }^{\circ} \mathrm{C} \\
\text { Minimum: } 18.5^{\circ} \mathrm{C} \\
\text { Precipitation: } 2550 \mathrm{~mm}\end{array}$ & $\begin{array}{l}\text { Cambisol } \\
\text { Fluvisol } \\
\text { Gleysol } \\
\text { Lithosol } \\
\text { Arenic regosol }\end{array}$ \\
\hline
\end{tabular}




\begin{tabular}{|c|c|c|c|c|}
\hline & & & & $\begin{array}{l}\text { Solonchak } \\
\text { Vertisol }\end{array}$ \\
\hline & Oaxaca & $\begin{array}{l}\text { Hot sub-humid: } 47 \% \\
\text { Hot humid: } 22 \% \\
\text { Temperate humid: } 16 \% \\
\text { Arid and semi-arid: } 11 \% \\
\text { Temperate subhumid: } 4 \%\end{array}$ & $\begin{array}{l}\text { Mean: } 22{ }^{\circ} \mathrm{C} \\
\text { Maximum: } 31{ }^{\circ} \mathrm{C} \\
\text { Minimum: } 12.5^{\circ} \mathrm{C} \\
\text { Precipitation: } 1550 \mathrm{~mm}\end{array}$ & $\begin{array}{l}\text { Phaeozem } \\
\text { Eutric fluvisol } \\
\text { Hortic luvisol } \\
\text { Luvisol } \\
\text { Vertic luvisol } \\
\text { Vertisol }\end{array}$ \\
\hline \multirow{3}{*}{ South } & Campeche & $\begin{array}{l}\text { Hot sub-humid: } 92 \% \\
\text { Hot humid: } 7.75 \% \\
\text { Semi-arid: } 0.05 \%\end{array}$ & $\begin{array}{l}\text { Mean: } 26.5^{\circ} \mathrm{C} \\
\text { Maximum: } 30^{\circ} \mathrm{C} \\
\text { Minimum: } 18^{\circ} \mathrm{C} \\
\text { Precipitation: } 1700 \mathrm{~mm}\end{array}$ & $\begin{array}{l}\text { Salic gleysol } \\
\text { Lithosol } \\
\text { Eutric regosol }\end{array}$ \\
\hline & Chiapas & $\begin{array}{l}\text { Hot humid: } 54 \% \\
\text { Hot sub-humid: } 40 \% \\
\text { Temperate humid: } 3 \% \\
\text { Temperate sub-humid: } \\
3 \%\end{array}$ & $\begin{array}{l}\text { Mean: } 23{ }^{\circ} \mathrm{C} \\
\text { Maximum: } 30{ }^{\circ} \mathrm{C} \\
\text { Minimum: } 17.5^{\circ} \mathrm{C} \\
\text { Precipitation: } 2600 \mathrm{~mm}\end{array}$ & $\begin{array}{l}\text { Acrisol } \\
\text { Cambisol } \\
\text { Luvisol } \\
\text { Solonchak }\end{array}$ \\
\hline & $\begin{array}{l}\text { Quintana } \\
\text { Roo }\end{array}$ & $\begin{array}{l}\text { Hot subhumid: } 99 \% \\
\text { Hot humid: } 1 \%\end{array}$ & $\begin{array}{l}\text { Mean: } 26{ }^{\circ} \mathrm{C} \\
\text { Maximum: } 33{ }^{\circ} \mathrm{C} \\
\text { Minimum: } 17^{\circ} \mathrm{C} \\
\text { Precipitation: } 1300 \mathrm{~mm}\end{array}$ & $\begin{array}{l}\text { Gleysol } \\
\text { Rendzic } \\
\text { Vertisol }\end{array}$ \\
\hline
\end{tabular}

Sources: INEGI, 2012; CONADESUCA, 2009.

Table S5. The most important pests, predators and parasitoids for sugarcane cultivation in Mexico

\begin{tabular}{|c|c|c|}
\hline Species & Order: Family & Common name in English (in Spanish) \\
\hline \multicolumn{3}{|l|}{ On leaves } \\
\hline Aeneolamia contigua Walker & Hemiptera: Cercopidae & Spittle bug (Mosca pinta o salivazo) \\
\hline A. contigua campecheana Fennah & Hemiptera: Cercopidae & Spittle bug (Mosca pinta o salivazo) \\
\hline A. contigua santa-rosae Fennah & Hemiptera: Cercopidae & Spittle bug (Mosca pinta o salivazo) \\
\hline A. albofasciata Walker & Hemiptera: Cercopidae & Spittle bug (Mosca pinta o salivazo) \\
\hline A. vilior Fowl. & Hemiptera: Cercopidae & Spittle bug (Mosca pinta o salivazo) \\
\hline A. postica Walker & Hemiptera: Cercopidae & Spittle bug (Mosca pinta o salivazo) \\
\hline A. postica occidentalis Fennah & Hemiptera: Cercopidae & Spittle bug (Mosca pinta o salivazo) \\
\hline Prosapia contigua Walker & Hemiptera: Cercopidae & Spittle bug (Mosca pinta o salivazo) \\
\hline P. bicinta Say. & Hemiptera: Cercopidae & Spittle bug (Mosca pinta o salivazo) \\
\hline P. bicinta angustata Walker & Hemiptera: Cercopidae & Spittle bug (Mosca pinta o salivazo) \\
\hline P. tepeana Fennah & Hemiptera: Cercopidae & Spittle bug (Mosca pinta o salivazo) \\
\hline P. simulans Walker & Hemiptera: Cercopidae & Spittle bug (Mosca pinta o salivazo) \\
\hline Zulia (Neozulia vilior Fowl.) & Hemiptera: Cercopidae & Spittle bug (Mosca pinta o salivazo) \\
\hline $\begin{array}{l}\text { Leptodictya tabida } \\
\text { (Herrich-Schaeffer) }\end{array}$ & Hemiptera: Tingidae & Sugarcane lace-bug (Chinche de encaje) \\
\hline Blissus leucopterus Say. & Hemiptera: Lygaeidae & Chinch bug (Chinche negra) \\
\hline $\begin{array}{l}\text { Saccharicoccus sacchari } \\
\text { Cockerell }\end{array}$ & Hemiptera: Pseudococcidae & Pink sugarcane mealybug (Chinche rosada) \\
\hline $\begin{array}{l}\text { Saccharosydne saccharivora } \\
\text { Westwood }\end{array}$ & Hemiptera: Delphacidae & Leafhopper (Saltahoja antillano) \\
\hline Sipha flava Forbes & Hemiptera: Aphididae & Yellow sugarcane aphid (Pulgón amarillo) \\
\hline Dysmicoccus boninsis Kuwana & Hemiptera: Pseudococcidae & Gray sugarcane mealybug (Chinche gris) \\
\hline
\end{tabular}


Mocis latipes Guenée

Trichoplusia ni Hübner

Cirphis latiuscula Herr. Sch.

Spodoptera frugiperda J. E. Smith

Elasmopalpus lignosellus Zeller

Schistocerca pallens Thunb

S. paranensis Burmeister

Chromacris colorata Serville

Taeniopoda auricornis Walker

Tropinotus mexicanus Burmeister

\section{On stems}

Diatrea considerata Heinrich

D. magnifactella Dyar

D. grandiosella Dyar

D. saccharalis Fabricius

D. veracruzana Box

D. lineolata Walker

D. muellerella Dyar \& Heinrich

Eoreuma loftini Dyar

Cholus morio Champion

\section{On roots}

Phyllophaga crinalis Bates

P. sturmi Bates

Anomala cincta Say

Cyclocephala fulgurata

Burmeister

Euetheola bidentata Burmeister

E. humillis Burmeister

E. rugiceps Le Conte

Golofa pusilla Arrow

Pyrophorus stella Candéze

Heterotermes tenuis Hagen

Amitermes beaumonti Banks

Reticulitermes flavipes Kollar

Radopholus similis (Cobb) Thorne

Pratylenchus brachyurus

Goldfrey.

Haplolaimus sp.

Criconema sp.

Sigmodon toltecus Saussure

S. arizonae Mearns

S. hispidus Say and Ord

S. mascotensis J. A. Allen

Oryzomys couesi Alston

Peromyscus leucopus Rafinesque

P. maniculatus Wagner

Handleyomys rostratus Merriam

Rattus rattus Linnaeus

Dipodomys phillipsii Gray
Lepidoptera: Noctuidae

Lepidoptera: Noctuidae

Lepidoptera: Noctuidae

Lepidoptera: Noctuidae

Lepidoptera: Pyralidae

Orthoptera: Acrididae

Orthoptera: Acrididae

Orthoptera: Acrididae

Orthoptera: Romaleidae

Orthoptera: Romaleidae

Lepidoptera: Crambidae

Lepidoptera: Crambidae

Lepidoptera: Crambidae

Lepidoptera: Crambidae

Lepidoptera: Crambidae

Lepidoptera: Crambidae

Lepidoptera: Crambidae

Lepidoptera: Crambidae

Coleoptera: Curculionidae

Coleoptera: Scarabaeidae

Coleoptera: Scarabaeidae

Coleoptera: Scarabaeidae

Coleoptera: Scarabaeidae

Coleoptera: Scarabaeidae

Coleoptera: Scarabaeidae

Coleoptera: Scarabaeidae

Coleoptera: Scarabaeidae

Coleoptera: Elateridae

Isoptera: Heterotermitidae

Isoptera: Termitidae

Isoptera: Rhinotermitidae

Tylenchida: Pratylenchidae

Tylenchida: Pratylenchidae

Tylenchida: Hoplolaimidae

Tylenchida: Criconematidae

Rodentia: Muridae

Rodentia: Muridae

Rodentia: Muridae

Rodentia: Muridae

Rodentia: Muridae

Rodentia: Muridae

Rodentia: Muridae

Rodentia: Muridae

Rodentia: Muridae

Rodentia: Heteromyidae
Striped grassworm (Gusano medidor)

Cabbage looper (Gusano falso medidor)

Army worms (Gusano soldado)

Fall armyworm (Gusano cogollero)

Lesser cornstalk borer (Barrenador coralillo)

Locust (Langosta)

Locust (Langosta)

Grasshopper (Chapulín)

Grasshopper (Chapulín)

Grasshopper (Chapulín)

Sugarcane borer (Barrenador del tallo)

Sugarcane borer (Barrenador del tallo)

Sugarcane borer (Barrenador del tallo)

Sugarcane borer (Barrenador del tallo)

Sugarcane borer (Barrenador del tallo)

Sugarcane borer (Barrenador del tallo)

Sugarcane borer (Barrenador del tallo)

Sugarcane borer (Barrenador del tallo)

Sugarcane stalk weevil (Picudo del tallo)

Masked chafers (Gallina ciega o mayate)

Masked chafers (Gallina ciega o mayate)

Masked chafers (Gallina ciega o mayate)

Masked chafers (Gallina ciega o mayate)

Sugarcane beetle (Mayatito de la caña)

Sugarcane beetle (Mayatito de la caña)

Sugarcane beetle (Mayatito de la caña)

Rhinoceros beetles (Mayate rinoceronte)

Wireworms (Gusanos de alambre)

Termite (Termitas)

Termite (Termitas)

Termite (Termitas)

Burrowing nematode (Nemátodo perforador)

Dagger nematode (Nemátodo daga)

Lance nematode (Nemátodo lanza)

Spine nematode (Nemátodo de la columna)

Rat (Rata cañera)

Rat (Rata cañera)

Hispid cotton rat (Rata algodonera)

Rat (Rata cañera)

Rat (Rata cañera)

Rat (Rata cañera)

Rat (Rata cañera)

Rat (Rata cañera)

Rat (Rata cañera)

Rat (Rata cañera) 
Liomys pictus Thomas

Orthogeomys hispidus Le Conte

O. grandis Thomas

Crathogeomys merriami merriami

Thomas

\section{Predators}

Coleomegilla maculata De Geer

Castolus plagiaticollis Stol

\section{Parasitoids}

Lixophaga diatraeae Townsend

Metagonistylum minense

Townsend

Paratheresia claripalpis Van der Wulp

Palpozenillia palpalis Aldrich

Trichogramma pretiosum Riley

T. minutum Riley

Telenomus alecto Crawford Iridomyrmex humilis Mayr Atta fervens Drury
Rodentia: Heteromyidae

Rodentia: Geomyidae

Rodentia: Geomyidae

Rodentia: Geomyidae

Coleoptera: Coccinellidae

Hemiptera: Reduviidae

Diptera: Tachinidae

Diptera: Tachinidae

Diptera: Tachinidae

Diptera: Tachinidae

Hymenoptera:

Trichogrammatidae

Hymenoptera:

Trichogrammatidae

Hymenoptera: Scelionidae

Hymenoptera: Formicidae Hymenoptera: Formicidae
Rat (Rata cañera)

Pocket gopher (Tuza)

Pocket gopher (Tuza)

Pocket gopher (Tuza)

Ladybird beetles (Catarina)

Predatory bugs (Chinches predadoras)

Cuban fly (Mosca cubana)

Amazon fly (Mosca amazónica)

Mexican fly (Mosca mexicana)

Tachinid parasite of sugarcane (Mosca de Tepic)

Egg parasitoid (Parásitos de los huevecillos)

Egg parasitoid (Parásitos de los huevecillos)

Egg parasitoid (Parásitos de los huevecillos)

Argentine ant (Hormiga argentina)

Leafcutter ant (Hormiga defoliadora)

Sources: Flores (2007); Vásquez-López et al., 2013.

Table S6. Most common diseases for sugarcane cultivation in Mexico

\begin{tabular}{|c|c|c|}
\hline Species & Type & Disease name in English (in Spanish) \\
\hline Cercospora longipes E. J. Butler & Fungal & Brow spot (Peca o mancha café) \\
\hline Leptosphaeria sacchari B. de Hann & Fungal & Ring spot (Mancha de anillo) \\
\hline Bipolaris sacchari (E. J. Butler) Shoemaker & Fungal & Eye spot (Mancha de ojo) \\
\hline Capnodium sp. & Fungal & Sooty mould (Fumagina de la hoja) \\
\hline $\begin{array}{l}\text { Anamorph: Fusarium moniliforme J. Sheld. } \\
\text { Gibberella subglutinans (E. T. Edwards) P. E. } \\
\text { Nelson, Toussoun \& Marasas }\end{array}$ & Fungal & Pokkah-boeng (Cogollo retorcido) \\
\hline Pythium spp. & Fungal & Pythium root rot (Pudrición del sistema radicular) \\
\hline Ceratocystis paradoxa (Dade) C. Moreau & Fungal & Pineapple disease (Enfermedad de la piña) \\
\hline $\begin{array}{l}\text { Phaeocytostroma sacchari (Ellis \& Everh.) B. } \\
\text { Sutton }\end{array}$ & Fungal & Rind disease (Enfermedad de la corteza ) \\
\hline $\begin{array}{l}\text { Marasmius sacchari Wakker } \\
\text { M. stenospilus Montagne }\end{array}$ & Fungal & $\begin{array}{l}\text { Marasmius basal stem, root and sheath rot } \\
\text { (Pudrición de la base del tallo, de la raíz y de la } \\
\text { vaina) }\end{array}$ \\
\hline $\begin{array}{l}\text { Cephalosporium sacchari E. J. Butler = } \\
\text { Fusarium sacchari (E. J. Butler) W. Gams }\end{array}$ & Fungal & Wilt (Marchitez) \\
\hline Cytospora sacchari E. J. Butler & Fungal & Sheath rot (Pudrición de la vaina) \\
\hline $\begin{array}{l}\text { Glomerella tucumanensis (Speg.) Arx \& E. } \\
\text { Müller = Physalospora tucumanensis Speg. }\end{array}$ & Fungal & Red rot (Pudrición roja del tallo) \\
\hline $\begin{array}{l}\text { Sporisorium scitamineum (Syd.) M.Piepenbr., } \\
\text { M. Stoll \& Oberw }\end{array}$ & Fungal & Smut (Carbón) \\
\hline Puccinia melanocephala Syd. \& P. Syd. & Fungal & Rust (Roya café) \\
\hline P. kuehnii (W. Krüger) E.J. Butler & Fungal & Orange rust (Roya naranja) \\
\hline Acidovoraz avanea Starr \& Burkholder & Bacterial & Red stripe (Raya roja) \\
\hline
\end{tabular}


Leifsonia xyli subsp. xyli (Davis et al.) Bacterial Ratoon stunt (Raquitismo de las socas)
Evtushenko

Xanthomonas albilineans (Ashby) Dowson. Bacterial Leaf scald (Escaldadura de la hoja)

Sugarcane mosaic virus (SCMV) Virus Mosaic (Mosaico de la caña)

Yellow leaf syndrome (YLS) Virus $\quad$ Yellow leaf (Hoja amarilla)

Sources: Chinea-Martín and Milanés-Ramos (2006); Flores (2007).

Table S7. Primary weed species for sugarcane cultivation in Mexico

\begin{tabular}{|c|c|c|}
\hline Species & Family & Common name in English (in Spanish) \\
\hline \multicolumn{3}{|l|}{ Annuals } \\
\hline Thunbergia alata Bojer ex Sims & Acanthaceae & Blackeyed Susan vine (Ojo de pájaro) \\
\hline Commelina diffusa Burm. $\mathrm{f}$. & Commelinaceae & Climbing dayflower (Tripa de pollo) \\
\hline Bidens pilosa $\mathrm{L}$. & Asteraceae & Beggarticks (Acahuale blanco) \\
\hline $\begin{array}{l}\text { Melampodium divaricatum (L.C. } \\
\text { Rich.) DC. }\end{array}$ & Asteraceae & Blackfoots (Botón de oro) \\
\hline Parthenium hysterophorus L. & Asteraceae & Santa Maria feverfew (Escoba amarga) \\
\hline Chamaesyce hirta (L.) Millsp. & Euphorbiaceae & Pillpod sandmat (Hierba de paloma) \\
\hline Pharbitis purpurea (L.) Voigt & Convolvulaceae & Morning glory (Bejuquillo) \\
\hline Digitaria ciliaris (Retz.) Koeler & Poaceae & Southern crabgrass (Zacate conejo) \\
\hline $\begin{array}{l}\text { Spermacoce assurgens Ruiz and } \\
\text { Pav. }\end{array}$ & Rubiaceae & False buttonweed (Celestina azul) \\
\hline Amaranthus viridis $\mathrm{L}$. & Amaranthaceae & Green amaranth (Bledo verde) \\
\hline A. hybridus L. & Amaranthaceae & Red amaranth (Quintonil) \\
\hline Heliotropium indicum $\mathrm{L}$. & Boraginaceae & Indian heliotrope (Molto) \\
\hline Ageratum houstonianum P. Mill. & Asteraceae & $\begin{array}{l}\text { Blue billygoat weed (Yerba del } \\
\text { zopilote) }\end{array}$ \\
\hline Euphorbia hyssopifolia L. & Euphorbiaceae & $\begin{array}{l}\text { Hyssop spurge (Hierba de la } \\
\text { golondrina) }\end{array}$ \\
\hline E. dentata Michx. & Euphorbiaceae & Toothed spurge (Lechosilla) \\
\hline Cenchrus echinatus $\mathrm{L}$. & Poaceae & Burgrass (Zacate cadillo) \\
\hline $\begin{array}{l}\text { Rottboellia cochinchinensis } \\
\text { (Lour.) Clayton }\end{array}$ & Poaceae & Itchgrass (Caminadora) \\
\hline $\begin{array}{l}\text { Senna obtusifolia (L.) H.S. Irwin } \\
\text { \& Barneby }\end{array}$ & Caesalpiniaceae & Java-bean (Palo zorrillo) \\
\hline $\begin{array}{l}\text { Phytolacca purpurascens A. Br. } \\
\text { et Bouché }\end{array}$ & Phytolaccaceae & Pokeweeds (Chichán) \\
\hline Brachiaria fasciculata B. & Poaceae & Signalgrass (Zacate de año) \\
\hline Solanum nigrum L. & Solanaceae & Black nightshade (Hierba mora) \\
\hline Conyza canadensis (L.) Cronquist & Asteraceae & Horseweed (Cola de caballo) \\
\hline Tithonia spp. & Asteraceae & Mexican sunflower (Gigantón) \\
\hline Momordica charantia $\mathrm{L}$. & Cucurbitaceae & Bitter melon (Melón amargo) \\
\hline Argemone mexicana $\mathrm{L}$. & Papaveraceae & Mexican prickly-poppy (Cardosanto) \\
\hline Plantago major $\mathrm{L}$. & Plantaginaceae & Broadleaf plantain (Llantén mayor) \\
\hline Portulaca oleracea L. & Portulacaceae & Purslane (Verdolaga) \\
\hline \multicolumn{3}{|l|}{ Perennials } \\
\hline Oxalis spp. & Oxalidaceae & Mexican oxalis (Trébol) \\
\hline Borreria spp. & Rubiaceae & False buttonweed (Estrella blanca) \\
\hline $\begin{array}{l}\text { Mecardonia procumbens (Mill.) } \\
\text { Small }\end{array}$ & Scrophulariaceae & Waterhyssop (Hierba té) \\
\hline Verbena spp. & Verbenaceae & Vervain (Verbena) \\
\hline
\end{tabular}


Talinum paniculatum (Jacq.)

Gaertn.

Cenchrus echinatus L.

Paspalum distichum $\mathrm{L}$.

P. natatum Flüggé

Brachiaria mutica (Forssk.) Stapf

Cynodon dactylon (L.) Pers.

Sida spp.

Mimosa pudica $\mathrm{L}$.

Sporobolus jacquemontii K.

Melinis repens (Willd.) Zizka

Setaria macrostachya Kunth

Megathyrsus maximus (Jacq.)

B.K. Simon and S. W. L. Jacobs

(Panicum maximum Jacq.)

Cynodon plectostachyus $\mathrm{P}$.

Sorghum halepense (L.) Pers.

Cyperus iria $\mathrm{L}$.

C. rotundus $\mathrm{L}$.

Ipomoea spp. (L.) Lam.
Portulacaceae

Poaceae

Poaceae

Poaceae

Poaceae

Poaceae

Malvaceae

Mimosaceae

Poaceae

Poaceae

Poaceae

Poaceae

Poaceae

Poaceae

Cyperaceae

Cyperaceae

Convolvulaceae
Big talinum (Rama de sapo)

Southern sandspur (Zacate cadillo)

Knotgrass (Camalote)

Bahia grass (Zacate bahía)

Signalgrass (Súrbana)

Bermuda grass (Zacate bermuda)

Fanpetals (Malva)

Sensitive plant (Dormilona)

American rat's tail grass (Zacate de mi casa)

Rose natal grass (Pasto rosado)

Large-spike bristlegrass (Zacate cola de zorra)

Guinea grass (Zacate privilegio)

Bermuda Grass (Pasto estrella)

Johnson grass (Zacate Johnson)

Rice flatsedge (Coquillo paragüita)

Nut grass (Coquillo rojo)

Whitestar potato (Enredadera)

Sources: CNPR (2013); CONABIO (2012).

Table S8. Products registered by the National Service of Health, Food Safety and Quality (Servicio Nacional de Sanidad, Inocuidad y Calidad Agroalimentaria, SENASICA) for the integrated management of weeds and pests of sugarcane in Mexico

\begin{tabular}{ccc}
\hline Chemical Group & Common Name & Commercial Names \\
\hline & & Weeds
\end{tabular}

\section{Growth regulators}

Agrester $400 \mathrm{CE}$, Esteron $47 \mathrm{M} /$ Formula 40, Uniamina $720 \mathrm{CE}$,

Phenoxycarboxilic acids

Benzoic acids

Pyridinecarboxilic acids
Herbipol 4-EB, Desmonte 4EB, Cuproester, Herbipol 334-E, Hierbester, 2,4-D Amina 72, Machetazo 2000, Novamina 480, Focus, Banvel 12-24, Crosser, Quron, Tordon 472-M, Diurpax, Resplandor 400

Dicamba

Picloram

Crosser, Quron, Tordon 472-M

\begin{tabular}{|c|c|c|}
\hline $\begin{array}{l}\text { Germination } \\
\text { inhibitors } \\
\text { Dinitroanilines }\end{array}$ & Pendimethalin & Prowl 400 \\
\hline \multicolumn{3}{|l|}{$\begin{array}{c}\text { Photosynthesis } \\
\text { inhibitors }\end{array}$} \\
\hline \multirow{2}{*}{ Triazines } & Atrazine & $\begin{array}{l}\text { Gesaprim Calibre } 90 \text { GDA, Agrox } 90 \text { DF, Tetrimex } 90 \text { DF, } \\
\text { Novaprin } 501 \mathrm{FW} \text {, Atrapol, Atrazine 500, Desyerbal 500, Combi } \\
80 \text { PH, Caña Z, Atramet Combi } 50 \text { SC, Marvel }\end{array}$ \\
\hline & Ametrine & $\begin{array}{l}\text { Ametrex } 80 \text { WG, Gesapax Combi } 80 \text { PH, Ametrex } 50 \mathrm{WP} \text {, } \\
\text { Ametrina } 500 \mathrm{FW} \text {, Novopax 501, Krismat } 75 \mathrm{GS} \text {, Caña Z, Atramet } \\
\text { Combi } 50 \text { SC, Diurpax, Resplandor 400, Sinerge } 500 \mathrm{CE}\end{array}$ \\
\hline Triazinones & Hexazinone & Hexapar 240 CE, Velpar K3, Advance \\
\hline Triazolinones & Amicarbazone & Orion \\
\hline Phenilureas & Diuron & Diurpax, Cention 800 FLO, Karmex 80 DF, Diurex 80 WG, \\
\hline
\end{tabular}


Guerrero 800 DF, Advance, Velpar K3, Karmex Plus, Gramocil

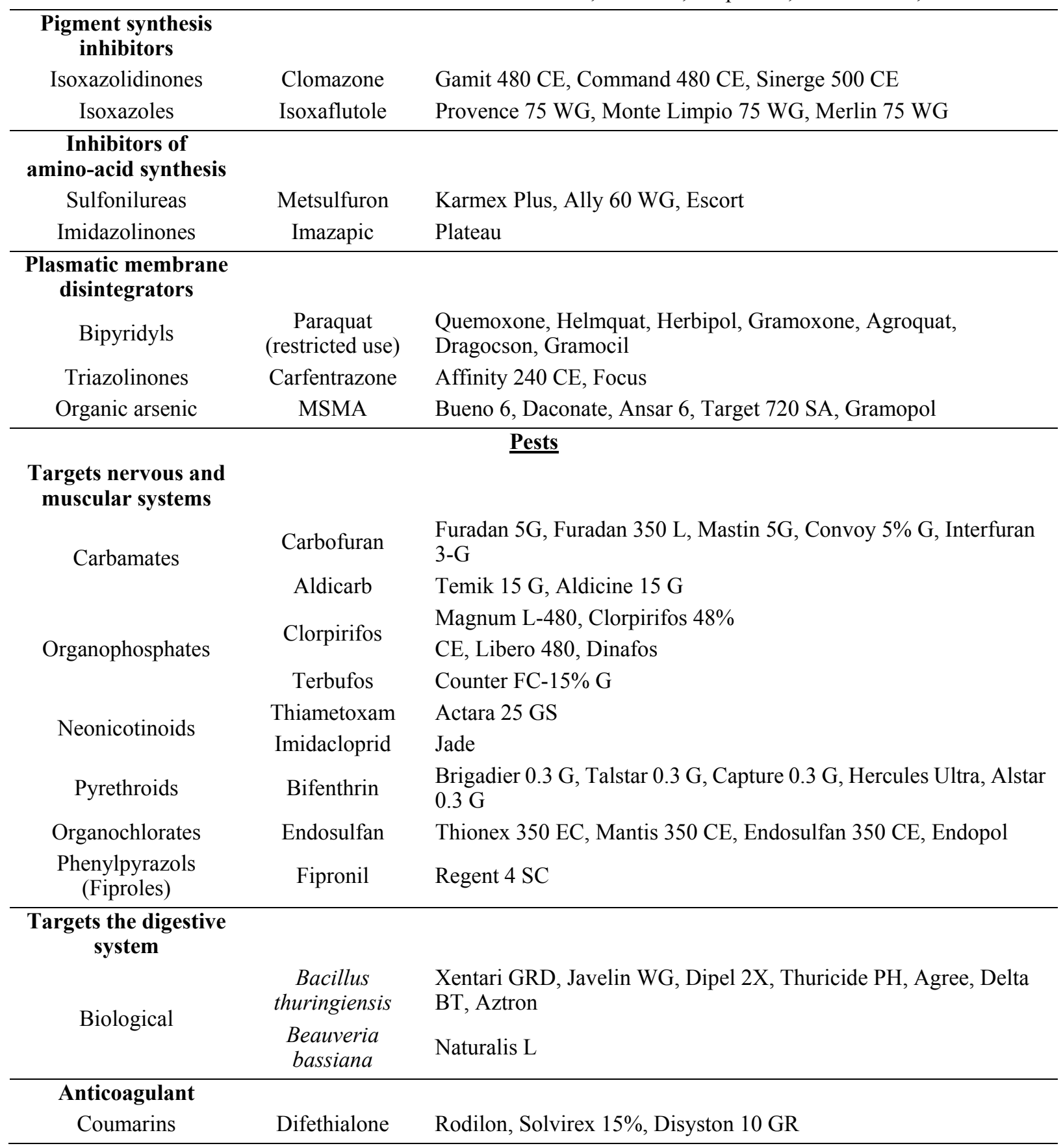

Source: SENASICA (2011). 
Table S9. Industrial groups and independent refineries involved in the processing of sugarcane primary material in Mexico and productivity level per refinery operating during the 2012/2013 harvest

\begin{tabular}{|c|c|c|c|}
\hline Industrial Group & Refinery & State & $\begin{array}{l}\text { Productivity } \\
\text { Level }\end{array}$ \\
\hline Agazucar S.A. de C.V. & Puga & Nayarit & Medium \\
\hline \multirow{9}{*}{$\begin{array}{l}\text { SAGARPA-FEESA } \\
\text { (Federal Government) }\end{array}$} & \multirow{2}{*}{$\begin{array}{c}\text { Atencingo } \\
\text { Casasano (La Abeja) }\end{array}$} & Puebla & Very high \\
\hline & & Morelos & Very high \\
\hline & El Modelo & Veracruz & High \\
\hline & El Potrero & Veracruz & Medium \\
\hline & Emiliano Zapata & Morelos & Very high \\
\hline & La Providencia & Veracruz & Medium \\
\hline & Plan de San Luis & San Luis Potosí & Very low \\
\hline & San Cristóbal & Veracruz & Low \\
\hline & San Miguelito & Veracruz & High \\
\hline \multirow{2}{*}{$\begin{array}{l}\text { Grupo Azucarero del } \\
\text { Trópico S.A. de C.V. }\end{array}$} & La Gloria & Veracruz & High \\
\hline & La Joya & Campeche & Very low \\
\hline \multirow{4}{*}{$\begin{array}{c}\text { Grupo Azucarero México } \\
\text { S.A. de C.V. }\end{array}$} & El Dorado & Sinaloa & High \\
\hline & José María Martínez (Tala) & Jalisco & High \\
\hline & Lázaro Cárdenas & Michoacán & High \\
\hline & Presidente Benito Juárez & Tabasco & Very low \\
\hline \multirow{6}{*}{ Grupo Beta San Miguel } & Constancia & Veracruz & Medium \\
\hline & Quesería & Colima & High \\
\hline & San Francisco Ameca & Jalisco & High \\
\hline & San Miguel del Naranjo & San Luis Potosí & Low \\
\hline & San Rafael de Pucté & Quintana Roo & Very low \\
\hline & Santa Rosalia (La Chontalpa) & Tabasco & Very low \\
\hline \multirow{3}{*}{ Grupo García González } & Calípam & Puebla & High \\
\hline & El Carmen & Veracruz & Medium \\
\hline & Nuevo San Francisco & Veracruz & Very low \\
\hline \multirow{3}{*}{ Grupo La Margarita } & Central Progreso & Veracruz & Low \\
\hline & José María Morelos & Jalisco & Medium \\
\hline & La Margarita & Oaxaca & Medium \\
\hline \multirow{2}{*}{ Grupo Motzorongo } & Central Motzorongo & Veracruz & Medium \\
\hline & El Refugio (Santa Isabel) & Oaxaca & Medium \\
\hline Grupo Pantaleón & Pánuco & Veracruz & High \\
\hline \multirow{3}{*}{ Grupo Porres } & Huixtla & Chiapas & High \\
\hline & San Pedro & Veracruz & Low \\
\hline & Santa Clara & Michoacán & High \\
\hline \multirow{2}{*}{$\begin{array}{c}\text { Grupo Promotora } \\
\text { Industrial Azucarera S.A. } \\
\text { de C.V. (PIASA) }\end{array}$} & Adolfo López Mateos & Oaxaca & Medium \\
\hline & Tres Valles & Veracruz & Low \\
\hline \multirow{3}{*}{ Grupo Sáenz } & Aarón Sáenz Garza & Tamaulipas & High \\
\hline & El Mante & Tamaulipas & Medium \\
\hline & Tamazula & Jalisco & Very high \\
\hline \multirow{3}{*}{$\begin{array}{c}\text { Ingenios Santos S.A. de } \\
\text { C.V. }\end{array}$} & Alianza Popular & San Luis Potosí & Very low \\
\hline & Bellavista & Jalisco & Medium \\
\hline & Cuatotolapan & Veracruz & Low \\
\hline
\end{tabular}




\begin{tabular}{cccc} 
& & & \\
& Pedernales & Michoacán & High \\
& Plan de Ayala & San Luis Potosí & Very low \\
& San Gabriel & Veracruz & Low \\
\hline \multirow{2}{*}{ Zucarmex } & Cía. Azucarera La Fe (Pujiltic) & Chiapas & High \\
& El Higo & Veracruz & High \\
& Mahuixtlán & Veracruz & High \\
& Melchor Ocampo & Jalisco & Very high \\
\hline Anance Regional (La Primavera) & Sinaloa & High \\
& Azuremex (Tenosique) & Tabasco & Very low \\
& El Molino & Nayarit & Medium \\
& Los Mochis & Sinaloa & High \\
& San José de Abajo & Veracruz & Low \\
& San Nicolás & Veracruz & Medium \\
\hline
\end{tabular}

Sources: MAM (2013); Aguilar-Rivera et al. (2012).

Table S10. Selection process for sugarcane varieties in Mexico

\begin{tabular}{|c|c|c|c|c|c|c|c|c|c|}
\hline \multirow[t]{2}{*}{ Phase } & \multicolumn{2}{|c|}{$\begin{array}{c}\text { Evaluation } \\
\text { period }\end{array}$} & \multirow[t]{2}{*}{$\begin{array}{l}\text { Selection } \\
\text { pressure }\end{array}$} & \multirow{2}{*}{$\begin{array}{c}\text { Estimated } \\
\text { number to } \\
\text { plant }\end{array}$} & \multirow[t]{2}{*}{ Nomenclature } & \multirow{2}{*}{$\begin{array}{c}\text { Experimental } \\
\text { plot }\end{array}$} & \multirow{2}{*}{$\begin{array}{l}\text { Total } \\
\text { area } \\
\text { (ha) }\end{array}$} & \multirow[t]{2}{*}{ Location } & \multirow[t]{2}{*}{ Activity } \\
\hline & Cycle & Months & & & & & & & \\
\hline Seedling & $\begin{array}{c}2^{\text {nd }} \\
\text { harvest }\end{array}$ & 18 & $20 \%$ & 30000 & Hybrids & $\begin{array}{c}1 \text { variety every } \\
\mathrm{m}\end{array}$ & 4.5 & $\begin{array}{l}\text { Experimental } \\
\text { field }\end{array}$ & $\begin{array}{c}\text { Applied } \\
\text { investigation }\end{array}$ \\
\hline Row & $\begin{array}{c}2^{\text {nd }} \\
\text { harvest }\end{array}$ & 24 & $20 \%$ & 6000 & Varieties & 1 row of $3 \mathrm{~m}$ & 4.5 & $\begin{array}{l}\text { Experimental } \\
\text { field }\end{array}$ & $\begin{array}{c}\text { Applied } \\
\text { investigation }\end{array}$ \\
\hline Stump & $\begin{array}{c}2^{\text {nd }} \\
\text { harvest }\end{array}$ & 24 & $20 \%$ & 6000 & Varieties & $\begin{array}{c}1 \text { stump every } \\
1.8 \mathrm{~m}\end{array}$ & 4.5 & $\begin{array}{l}\text { Experimental } \\
\text { field }\end{array}$ & $\begin{array}{c}\text { Applied } \\
\text { investigation }\end{array}$ \\
\hline Parcel & $\begin{array}{c}2^{\text {nd }} \\
\text { harvest }\end{array}$ & 24 & $20 \%$ & 1200 & Varieties & 3 rows of $5 \mathrm{~m}$ & 5 & $\begin{array}{l}\text { Experimental } \\
\text { field }\end{array}$ & $\begin{array}{c}\text { Applied } \\
\text { investigation }\end{array}$ \\
\hline Multiplication I & Planting & $10-12$ & --- & 240 & Varieties & 4 rows of $5 \mathrm{~m}$ & 1.2 & $\begin{array}{l}\text { Experimental } \\
\text { field }\end{array}$ & $\begin{array}{c}\text { Applied } \\
\text { investigation }\end{array}$ \\
\hline Adaptability test & $\begin{array}{c}2^{\text {nd }} \\
\text { harvest }\end{array}$ & 24 & $20 \%$ & 240 & Varieties & 3 rows of $10 \mathrm{~m}$ & 2 & $\begin{array}{l}\text { Experimental } \\
\text { field }\end{array}$ & $\begin{array}{c}\text { Applied } \\
\text { investigation }\end{array}$ \\
\hline Multiplication II & Planting & $10-12$ & --- & 48 & Varieties & 5 rows of $25 \mathrm{~m}$ & 1.2 & $\begin{array}{l}\text { Experimental } \\
\text { field }\end{array}$ & $\begin{array}{c}\text { Applied } \\
\text { investigation }\end{array}$ \\
\hline $\begin{array}{l}\text { Agroindustrial } \\
\text { evaluation }\end{array}$ & $\begin{array}{l}>2^{\text {nd }} \\
\text { harvest }\end{array}$ & $38-42$ & $20 \%$ & 48 & Varieties & 6 rows of $12 \mathrm{~m}$ & 1 & $\begin{array}{l}\text { Experimental } \\
\text { field }\end{array}$ & $\begin{array}{c}\text { Applied } \\
\text { investigation }\end{array}$ \\
\hline Multiplication III & Planting & $10-12$ & --- & $1-10$ & $\begin{array}{c}\text { Promising } \\
\text { varieties }\end{array}$ & $\begin{array}{c}15 \text { rows of } 50 \\
\mathrm{~m}\end{array}$ & $1.2-12$ & $\begin{array}{l}\text { Experimental or } \\
\text { commercial } \\
\text { field }\end{array}$ & $\begin{array}{c}\text { Applied } \\
\text { investigation }\end{array}$ \\
\hline $\begin{array}{l}\text { Semicommercial } \\
\text { test }\end{array}$ & Planting & $10-12$ & --- & $1-10$ & $\begin{array}{l}\text { Prospective } \\
\text { commercial } \\
\text { varieties }\end{array}$ & 1 ha & $1-10$ & $\begin{array}{l}\text { Commercial } \\
\text { field }\end{array}$ & $\begin{array}{l}\text { Experimental } \\
\text { development }\end{array}$ \\
\hline Nursery seedbed & Planting & $10-12$ & --- & $1-10$ & $\begin{array}{l}\text { Available } \\
\text { varieties }\end{array}$ & 10 ha & $10-100$ & $\begin{array}{l}\text { Commercial } \\
\text { field }\end{array}$ & Development \\
\hline
\end{tabular}

Source: IMPA (1983).

\section{Copyrights}

Copyright for this article is retained by the author(s), with first publication rights granted to the journal.

This is an open-access article distributed under the terms and conditions of the Creative Commons Attribution license (http://creativecommons.org/licenses/by/3.0/). 